Chicago-Kent College of Law

Scholarly Commons @ IIT Chicago-Kent College of Law

February 1991

\title{
The First Duty of Government: Protection, Liberty and the Fourteenth Amendment
}

Steven J. Heyman

IIT Chicago-Kent College of Law, sheyman@kentlaw.iit.edu

Follow this and additional works at: https://scholarship.kentlaw.iit.edu/fac_schol

Part of the Fourteenth Amendment Commons

\section{Recommended Citation}

Steven J. Heyman, The First Duty of Government: Protection, Liberty and the Fourteenth Amendment, 41 Duke L.J. 507 (1991).

Available at: https://scholarship.kentlaw.iit.edu/fac_schol/312

This Article is brought to you for free and open access by the Faculty Scholarship at Scholarly Commons @ IIT Chicago-Kent College of Law. It has been accepted for inclusion in All Faculty Scholarship by an authorized administrator of Scholarly Commons @ IIT Chicago-Kent College of Law. For more information, please contact jwenger@kentlaw.iit.edu, ebarney@kentlaw.iit.edu. 


\title{
THE FIRST DUTY OF GOVERNMENT: PROTECTION, LIBERTY AND THE FOURTEENTH AMENDMENT
}

\author{
STEven J. HEYMAN*
}

INTRODUCTION $\ldots \ldots \ldots \ldots \ldots \ldots \ldots \ldots \ldots \ldots \ldots \ldots \ldots \ldots \ldots . \ldots \ldots$

I. The Right to Protection in the ANglo-AmericaN



A. The Origins of the Right to Protection ............ 512

1. The Common Law Tradition and the Original

Contract.............................. 513

2. The Social Contract and Locke's Second Treatise... 514

3. Eighteenth-Century Constitutional Theory ........ 516

B. The Right to Protection in Early American

Constitutionalism ........................... 520

1. The Revolution ........................ 521

2. The First State Constitutions .............. 522

3. The Federal Constitution ................. 524

C. Protection and Liberty .................... 526

II. The Legal Meaning of Protection $\ldots \ldots \ldots \ldots \ldots \ldots .530$

A. The Status of Freeman and Citizen ............. 531

B. Recognition of Substantive Rights............... 532

C. Enforcement of Legal Rights .................. 534

1. Self-Defense ......................... 534

2. Civil Protection ...................... 534

3. Criminal Protection ................... 536

4. Prevention of Injury .................... 537

a. Security of the peace ................. 537

b. Protection by peace officers ............... 538

* Assistant Professor of Law, Chicago-Kent College of Law, Illinois Institute of Technology. A.B. 1979, J.D. 1984, Harvard University. I wish to thank many friends and colleagues for their thoughtful comments on earlier versions of this Article, including Akhil Reed Amar, Alison Baldwin, Lance Banning, Anita Bernstein, Richard Collins, Jacob Corré, Michael Kent Curtis, Stuart Deutsch, David Gerber, Philip Hamburger, Linda Hirshman, Howard Klemme, Michael Knoll, James Lindgren, Kerry Macintosh, Joan Meier, Sheldon Nahmod, Dale Nance, Steven D. Smith, Margaret Stewart, Arthur Travers, Richard Warner, Marianne Wesson, and Richard Wright. Invaluable research assistance was provided by Shari Lefkoff, Regina Drexler, Anne Gerrity, Susan Laser-Baer, and Laura Finnegan. My work was supported by the Marshall D. Ewell Research Fund.

This Article is dedicated to the memory of Paul A. Freund. 
. c. Communal liability ........................ 541

d. The creation of modern police forces........... 543

5. Conclusion .................................. 545

III. The Fourteenth Amendment ................... 545

A. The Need for a Federal Guarantee of the Right to

Protection ...................................... 546

B. The Adoption of the Civil Rights Act and the Fourteenth Amendment ................................ 550

C. The Right to Protection Under the Civil Rights Act and the Fourteenth Amendment ...................... 554

1. The Privileges or Immunities Clause ............ 555

2. The Due Process Clause ..................... 557

3. The Equal Protection Clause .................. 563

D. The Meaning of Protection ..................... 566

1. Civil Protection ........................... 566

2. Criminal Protection ......................... 567

3. Prevention of Injury ....................... 569



"The first duty of the Government is to afford protection to its citizens." 1

\section{INTRODUCTION}

On January 22, 1983, Joshua DeShaney, age four, was brought to the emergency room of a Wisconsin hospital with multiple bruises and abrasions. ${ }^{2}$ Suspecting child abuse, the hospital staff notified the County Department of Social Services, which immediately obtained custody of Joshua, only to return him to his father's home a few days later. Over the next fifteen months, the Department received constant reports indicating that Joshua was being seriously abused, but it failed to take any further action to protect him. On March 8, 1984, Joshua's father beat him so severely that he suffered massive brain damage, leaving him profoundly retarded and confined to an institution for the rest of his life.

In DeShaney v. Winnebago County Department of Social Services, ${ }^{3}$ the Supreme Court ruled that the Department's failure to protect Joshua

1. Cong. GlobE, 39th Cong., 2d Sess. 101 (1867) (remarks of Rep. Farnsworth) (debating Reconstruction Act of 1867).

2. The facts in this paragraph are derived from the opinion of the Supreme Court in DeShaney v. Winnebago County Dep't of Social Servs., 489 U.S. 189, 191-93 (1989), and from the unpublished opinion of the district court below, DeShaney v. DeShaney, No. 85-C-310, slip op. at 3-14 (E.D. Wis. June 20, 1986), reprinted in Appendix to Petition for Writ of Certiorari at 50-61, DeShaney (No. 87154).

3. 489 U.S. 189 (1989). 
did not violate the Federal Constitution. Chief Justice Rehnquist maintained that nothing in the language or history of the Due Process Clause of the Fourteenth Amendment required a state to protect its citizens from private violence. That clause, he observed, "is phrased as a limitation": "It forbids the State itself to deprive individuals of life, liberty, or property without 'due process of law,' but its language cannot fairly be extended to impose an affirmative obligation on the State" to protect these interests "against invasion by private actors." 4 This interpretation was reinforced by the history of the Clause, which indicated that "[i]ts purpose was to protect the people from the State, not to ensure that the State protected them from each other."5

The broader constitutional theory underlying this interpretation was articulated by Judge Richard Posner of the Court of Appeals for the Seventh Circuit. 6 According to Posner, the Constitution is "a charter of negative rather than positive liberties,"7 a view that is compelled by the original understanding:

The men who wrote the Bill of Rights were not concerned that government might do too little for the people but that it might do too much to them. The Fourteenth Amendment, adopted in 1868 at the height of laissez-faire thinking, sought to protect Americans from oppression by state government, not to secure them basic governmental services. $^{8}$

DeShaney thus has crucial implications for constitutional law and theory. In addition to rejecting a constitutional right to protection, DeShaney implies that the Constitution protects only negative libertyfreedom from governmental oppression-while imposing no positive obligations on government.

This Article challenges DeShaney on its own ground-the original understanding of the Fourteenth Amendment. As I shall argue, the congressional debates on the Fourteenth Amendment show that establishing a federal constitutional right to protection was one of the central purposes of the Amendment.

The principal aim of the Fourteenth Amendment was not to create new rights, but rather to incorporate into the Federal Constitution the fundamental rights that individuals already possessed under general constitutional theory, but that the states had failed to enforce adequately.

4. Id. at 195 .

5. Id. at 196.

6. See DeShaney v. Winnebago County Dep't of Social Servs., 812 F.2d 298 (7th Cir. 1987), aff'd, 489 U.S. 189 (1989); Jackson v. City of Joliet, 715 F.2d 1200 (7th Cir. 1983); Bowers v. DeVito, 686 F.2d 616 (7th Cir. 1982).

7. Jackson, 715 F.2d at 1203.

8. Id. 
For this reason, the Fourteenth Amendment must be understood against the background of constitutional and legal theory before the Civil War.

In Part I, I trace the origins and development of the right to protection in Anglo-American constitutionalism. With its roots in the common law tradition and social contract theory, the right to protection in life, liberty, and property became a central principle of American constitutional thought by the time of the Revolution. This principle was expressed in the first state constitutions and was implicit in the Federal Constitution, which divided the function of protection between the state and federal governments.

Part I also explores the conception of liberty in American constitutional and legal thought between the Revolution and the Civil War. Contrary to Posner's view, the classical conception of liberty was not merely negative, but had a crucial positive dimension-the protection of individual rights under law. ${ }^{9}$

As I show in Part II, the right to protection was not merely a matter of constitutional theory, but a doctrine with concrete legal meaning. In the common law tradition, the protection of the law implied both the recognition of fundamental rights by law, and the enforcement of such rights by government. The paradigmatic instance was the government's duty to protect individuals against violence. By the middle of the nineteenth century, this duty was understood to include not only the enforcement of civil and criminal law with respect to injuries already committed, but also the responsibility to prevent violence before it occurred.

In Part III, I turn to the congressional debates over the Fourteenth Amendment. As these debates show, the members of the Thirty-Ninth Congress fully shared the classical view on the right to protection. The widespread violence and discrimination against blacks in the South after the Civil War convinced most Republicans that the states could not be relied upon to protect the fundamental rights of all persons. A central purpose of the Fourteenth Amendment was to compel the states to fulfill this obligation, by incorporating it into the Federal Constitution and empowering the national government to enforce it.

The three clauses of Section 1 of the Fourteenth Amendment secured the right to protection in different ways. Protection was one of the fundamental rights of citizenship secured by the Privileges or Immunities

9. In this Article, I shall use the term "classical" to refer to American thought between the Revolution and the Civil War, and to the sources of that thought in the English tradition. As this usage suggests-and as I try to show in Parts I and II-American thought during this period expressed a set of common themes regarding the nature of individual rights and the ends of government. 
Clause. It also was implicit in the Due Process Clause, which was understood in the classical tradition to guarantee the protection of law to an individual's rights to life, liberty, and property, except where those rights had been held forfeited by due process of law. Finally, the Equal Protection Clause commanded that the states afford protection to all citizens in an impartial manner. In short, the Fourteenth Amendment was understood to incorporate the right to protection, as that right was understood in the classical tradition, into the Federal Constitution. ${ }^{10}$

This conclusion may seem surprising. During the twentieth century, and especially since the New Deal, the positive functions of government have expanded dramatically. The modern state undertakes to afford not only protection, but also at least a modicum of income, housing, health care, education, and other services. From a contemporary perspective, it is natural to identify all of these positive functions with the modern welfare state, and to assume that constitutionalism before the twentieth century was concerned solely with negative liberties. ${ }^{11}$

As I shall show, however, this view is seriously misleading. Although the positive role of government has reached a zenith since the New Deal, it does not follow that the state had no positive functions before that time. The classical state had a crucial positive function-the protection of rights. This function was not regarded as a mere "service"

10. For earlier discussions of the Fourteenth Amendment and the right to protection, see JACOBUS TENBRoEk, EQUAL UNDER LAW (rev. ed. 1965); Earl M. Maltz, The Concept of Equal Protection of the Laws-A Historical Inquiry, 22 SAN DIEgo L. REv, 499 (1985); Aviam Soifer, Protecting Civil Rights: A Critique of Raoul Berger's History, 54 N.Y.U. L. REV. 651 (1979). Unlike these works, which discuss the concept of protection in general terms, the present Article focuses on protection against private violence, the crucial issue raised in DeShaney. Moreover, I seek to explore both the constitutional background and the legal content of the right to protection in a more comprehensive way than have previous studies.

For a brief but powerful attack on Judge Posner's and Chief Justice Rehnquist's use of history in DeShaney, see Aviam Soifer, Moral Ambition, Formalism, and the "Free World" of DeShaney, 57 GEO. WASH. L. REV, 1513, 1521-26 (1989).

11. The assumption that a right to protection is antithetical to traditional legal theory is so pervasive that it appears to be shared even by many of DeShaney's strongest critics. For example, Susan Bandes, while noting the historical arguments for a duty of protection, argues that the hostility toward affirmative duties derives from the Anglo-American common law tradition and Western liberal political philosophy. See Susan Bandes, The Negative Constitution: A Critique, 88 MrCH. L. REV. 2271, 2308-26 (1990). Similarly, Laurence Tribe criticizes DeShaney as reflecting a premodern, Newtonian view of the legal universe, according to which the state is neutral and detached from a "natural, pre-political order" of private life. Appropriating the insights of twentiethcentury physics, Tribe argues that the state inevitably shapes the world that it observes, and thus bears some responsibility for its impact on that world. See Laurence H. Tribe, The Curvature of Constitutional Space: What Lawyers Can Learn from Modern Physics, 103 HARV. L. Rev. 1, 7-14 (1989). Presumably, American law before the twentieth century reflected the Newtonian view that Tribe criticizes. 
on a level with other benefits a state might choose to provide, but rather as the most fundamental obligation the government owed to its citizens.

My aims in this Article are both critical and positive. From a critical point of view, I hope to demonstrate that the Posner-Rehnquist view is indefensible, and that the history of the Fourteenth Amendment in no way forecloses recognition of a constitutional right to protection. From a positive perspective, this Article is intended as a contribution to the current debate over whether such a right should be recognized. In exploring the original understanding, I do not mean to imply that original intent should be binding in constitutional interpretation. ${ }^{12}$ Instead, the original understanding may be regarded as a starting point in a continuing debate over the meaning of the Constitution. As I shall argue, that understanding points strongly toward recognizing a constitutional right to protection.

\section{The Right to Protection in the Anglo-American CONSTITUTIONAL TRADITION}

\section{A. The Origins of the Right to Protection}

"[E]very member of society," asserted the Pennsylvania Constitution of 1776, "hath a right to be protected in the enjoyment of life, liberty and property."13 This declaration-which was soon echoed in the constitutions of Delaware, Massachusetts, and New Hampshire ${ }^{14}$-expressed a fundamental principle of American constitutional thought by the time of the Revolution.

12. For some leading contributions to the debate over the role of original understanding in constitutional interpretation, see JoHN H. ELY, DEMOCRACY AND DisTrusT 1-41 (1980); Paul Brest, The Misconceived Quest for the Original Understanding, 60 B.U. L. REV. 204 (1980); Richard S. Kay, Adherence to the Original Intentions in Constitutional Adjudication: Three Objections and Responses, 82 Nw. U. L. REv. 226 (1988); Mark V. Tushnet, Following the Rules Laid Down: A Critique of Interpretivism and Neutral Principles, 96 HARv. L. REv. 781 (1983). Although the degree of weight to be accorded original understanding is intensely controversial, few deny that it is one important source of constitutional meaning. This view is shared even by many of those most critical of original understanding. See, e.g., Brest, supra, at 205 (Text and original history should be accorded "presumptive weight," but should not be treated as "authoritative and binding.").

13. PA. CONST. of 1776, Declaration of Rights, art. VIII, reprinted in 8 SOURCES AND DocuMENTS OF UNITEd STATES CONSTITUTIONS 278 (William F. Swindler ed., 1973-1979) [hereinafter STATE CONSTITUTIONS].

14. See Del. Declaration of Rights and Fundamental Rules of 1776 , art. 10 , reprinted in 2 STATE CONSTITUTIONS, supra note 13, at 198; MASs. CoNST. of 1780, pt. I, art. X, reprinted in 5 State CONSTITUTIONS, supra note 13, at 94; N.H. CoNST. of 1784, Bill of Rights, art. XII, reprinted in 6 STATE CONSTTTUTIONS, supra note 13, at 345; $c f$. N.Y. CoNST. of 1777, art. XL, reprinted in 7 STATE CONSTITUTIONS, supra note 13, at 179 ("it is the duty of every man who enjoys the protection of society to be prepared and willing to defend it"). Vermont's first constitution (and all subsequent constitutions) contained a similar provision. See VT. CoNST. of 1777, ch. I, art. IX, 
The right to protection did not originate in America, however, but was inherited from English constitutionalism. Its roots lay in the common law tradition and natural rights theory. It is necessary to explore these sources to understand the concept of protection in American constitutional thought. ${ }^{15}$

1. The Common Law Tradition and the Original Contract. The right to protection has deep roots in the English legal tradition. Under traditional doctrine, every loyal subject was entitled to the king's protection. ${ }^{16}$ This doctrine received its classic expression in the writings of Sir Edward Coke. In Calvin's Case, ${ }^{17}$ Coke defined the relationship between sovereign and subject in terms of a "mutual bond and obligation," under which the subject owed allegiance or obedience, while the sovereign was bound "to govern and protect his subjects." 18 According to Coke, these reciprocal obligations were inherent in the very nature of the relationship between king and subject. ${ }^{19}$

As Coke made clear, the king's duty of protection included the obligation to protect his subjects from violence. ${ }^{20}$ The king afforded such protection through his laws and through the legal process, which provided means for the enforcement of rights. ${ }^{21}$ Thus, to be under the king's protection was to be under the "protection of the law."22

reprinted in 9 STATE CONSTITUTIONS, supra note 13, at 490. Vermont was not admitted into the Union until 1791.

For further discussion of these state constitutional provisions, see infra text accompanying notes 79-90.

15. For a brief overview of these sources, see Earl M. Maltz, Fourteenth Amendment Concepts in the Antebellum Era, 32 AM. J. LEGAL Hist. 305, 320-21 (1988).

16. See ANthony Fitz-Herbert, The New NATURA Brevium *29H (translation of work first published in 1534). The origins of this doctrine, which was fully established by the end of the thirteenth century, are traced in Frederick Pollock, The King's Peace, in Oxford Lectures AND OTHER DisCOURSES 65, 88-90 (1890).

17. 7 Co. Rep. 1a, 77 Eng. Rep. 377 (1608). For an excellent discussion of Calvin's Case and its role in the growth of American citizenship, see JAMEs KETTNER, THE DEVELOPMENT OF AMERICAN CITIZENSHIP, 1608-1870, at 7-8, 16-28 (1978).

18. 7 Co. Rep. at $4 b-5 a, 77$ Eng. Rep. at 382. For Coke these reciprocal obligations were summed up in the maxim "protectio trahit subjectionem, et subjectio protectionem": protection im. plies subjection, and subjection protection. Id. at 5a, 77 Eng. Rep. at 382.

19. See id. at $4 b-5 a, 77$ Eng. Rep. at 382.

20. See id. at 8a, 77 Eng. Rep. at 386 (The object of "the King's protection" is to ensure "that his subjects in all places may be protected from violence, and that justice may equally be administered to all his subjects."); see also 1 EDWARD COKE, INSTITUTES OF THE LAws OF ENGLAND *130a (The subject's right to protection entails "the safetie of his person, servants and goods, lands and tenements, whereof he is lawfully possessed, from violence, unlawfull molestation or wrong.").

21. See 1 COKE, supra note 20 , at $* 130$ a.

22. 3 id. at *126a (" $[F]$ or the law and the kings writs are the things whereby a man is protected and aided, so as he that is out of the kings protection, is out of the aid and protection of the law."); see also 1 id. at $* 130$ a (same). 
Coke's formulation of the reciprocal obligations of king and subject was soon accepted as a fundamental principle of English constitutionalism. Over the next century and a half, however, the basis of this doctrine was transformed. For Coke, the relationship between subject and ruler arose from the law of nature, and hence was immutable. ${ }^{23}$ During the seventeenth and eighteenth centuries, political obligation came to be regarded as based not on nature, but on consent. Accordingly, in constitutional theory, Coke's doctrine was transformed into a conception of an "original contract" between king and people, under which the people promised obedience in return for the ruler's protection. ${ }^{24}$ Under this conception, if the king failed to protect the rights of his subjects, their duty to obey was also at an end.

2. The Social Contract and Locke's Second Treatise. The second major source of the right to protection in Anglo-American constitutionalism was the theory of natural rights and the social contract. The most influential exposition of this theory was John Locke's Second Treatise of Government. ${ }^{25}$ Whereas Coke based the right to protection on the natural bond of allegiance between king and subject, Locke based it on the consent of free individuals to enter into society and establish government for the preservation of their natural rights. ${ }^{26}$

According to Locke, individuals are not naturally subject to a sovereign. Instead, the state of nature is a "State of perfect Freedom," where each individual is free to act as he thinks fit, without depending on the will of others. ${ }^{27}$ By the same token, the natural state of mankind is one of equality, in which free and independent individuals live without any "Subordination or Subjection."28

In a state of nature, men are not subject to positive laws, but only to the law of nature, which Locke identified with reason. ${ }^{29}$ That law teaches "that being all equal and independent, no one ought to harm

23. See Calvin's Case, 7 Co. Rep. at 12b-14b, 77 Eng. Rep. at 392-94.

24. See 1 WILliam Blackstone, Commentaries on the Laws of ENgland 233 (St. George Tucker ed., 1803 \& photo. reprint 1969). On the theory of the original contract in the mideighteenth century, see 2 JoHN P. REID, A Constitutional History OF THE AMERICAN Revolution: The Authority to TAX 55-60 (1987); GORdON S. WOOD, THE CREation Of THE AMERICAN REPUBLIC, 1776-1787, at 268-73 (1969).

25. JOHN LOCKE, Two TREATISES OF GOVERNMENT (Peter Laslett ed., student ed. 1988) (3d ed. 1698). All references to the Two Treatises in this Article are to the Second Treatise.

26. See KETTNER, supra note 17, at 44-61 (discussing contrasting views of political obligation held by Coke and Locke).

27. LOCKE, supra note $25, \S 4$.

28. Id. For further discussion of Locke's conception of equality and its relation to equal protection, see infra text accompanying notes 367-76.

29. See Locke, supra note $25, \S 6$. In order to accurately represent the thought of Locke and other classical writers, I shall follow their use of masculine language in describing their writings. 
another in his Life, Health, Liberty, or Possessions."30 Locke maintained that, in a state of nature, every individual has the right to enforce the law of nature by restraining and punishing violations of natural rights. ${ }^{31}$

In a state of nature, however, an individual often lacks the power to defend himself against invasion by others, rendering the enjoyment of his rights "very unsecure." 32 For this reason, individuals agree to form a community "for the mutual Preservation of their Lives, Liberties and Estates," which Locke comprehensively termed "Property."33 Under the terms of this compact, each individual gives up his natural power to act for his own preservation "to be regulated by the Laws made by the Society, so far forth as the preservation of himself, and the rest of that Society shall require."34 In addition, he "engages his natural force . . . to assist the Executive Power of the Society, as the law thereof shall require."35 In return, the individual obtains not only benefits from "the labour, assistance, and society of others in the same Community," but also "protection from its whole strength." 36 In short, according to Locke, the end of government is to direct "the force of all the subjects of the commonwealth" for the purpose of "preserving the members of the commonwealth in peace from injury and violence." 37

Locke emphasized that, because government is established for this purpose, it is "obliged" to secure every individual's life, liberty, and property. ${ }^{38}$ When it acts contrary to this trust, the government is dissolved and the community regains the right to establish a new form of government. ${ }^{39}$ Such dissolution occurs, in Locke's view, where the government invades the rights of subjects, or where it fails to use its power to secure those rights. ${ }^{40}$ Locke implied that the Glorious Revolution of 1688, in which King James II was dethroned and replaced by William and Mary, was justified on these grounds. ${ }^{41}$

30. Id.

31. See id. $\$ \S 7-12$.

32. Id. $\S \S 123,126$.

33. Id. § 123.

34. Id. $\S 129$.

35. Id. $\S 130$.

36. Id. (emphasis added). For other references to protection as the end of society and government, see id. $\$ \S 122,140,211,227$.

37. JoHN LOCKE, Third Letter on Toleration, in 6 COLlECTED WORKs 214 (1801), quoted in LockE, supra note $25, \S 135$ (editor's note).

38. See LockE, supra note $25, \S 131$.

39. See id. $\$ \S 211-243$.

40. See id. $\$ \S 219,221-222$.

41. Locke published the $T$ wo Treatises with the avowed object of justifying the Revolution. In a passage evidently referring to James's withdrawal from the kingdom during the Revolution, Locke wrote that the government was dissolved: 
Natural rights theory, which was radical at the time that Locke wrote, ${ }^{42}$ was gradually absorbed into mainstream English thought during the following century. Moreover, it was forcefully articulated during that period by a small group of radical Whig opposition writers, who had a crucial impact on the development of American political thought in the decades leading up to the Revolution. ${ }^{43}$ It was a canon of radical Whig thought that government existed to protect the natural rights of its subjects. As John Trenchard and Thomas Gordon wrote in Cato's Letters:

[M]utual Protection and Assistance is the only reasonable purpose of all reasonable Societies. To make such Protection practicable, Magistracy was formed, with power to defend the Innocent from Violence, and to punish those that offered it .... In order to this ... End, the Magistrate is intrusted with conducting and applying the united Force of the Community; and with exacting such a Share of every Man's Property, as is necessary to preserve the Whole, and to defend every Man and his Property from foreign and domestick Injuries.44

3. Eighteenth-Century Constitutional Theory. Thus, by the end of the seventeenth century, the most important theoretical bases of the right to protection had been articulated: the common law doctrine of allegiance and protection; the original contract between king and people; and the theory of natural rights and the social contract. By the mideighteenth century, each of these concepts had been incorporated into the mainstream of English constitutional theory. The classic articulation of this theory was the Commentaries on the Laws of England published by Sir William Blackstone between 1765 and 1769.45

when he who has the Supream Executive Power, neglects and abandons that charge, so that the Laws already made can no longer be put in execution.... Where there is no longer the administration of Justice, for the securing of Mens Rights, nor any remaining Power within the Community to direct the Force, or provide for the Necessities of the publick, there certainly is no Government left. Where the Laws cannot be executed, it is all one as if there were no Laws.

Id. $\S 219$.

42. See Richard Ashcraft, Revolutionary Polttics and Locke's Two Treatises of GOVERNMENT 521-89 (1986).

43. On the radical opposition writers and their influence, see BERNARD BAILYN, THE IDEOLOGICAL ORIGINS OF THE AMERICAN REVOLUTION 3454 (1967).

44. Cato's Letrers No. 62, at 245 (London 3d ed. 1733). On Cato's Letters, see Bailyn, supra note 43 , at $35-36$.

In recent years, radical Whig writers such as Trenchard and Gordon have often been portrayed as "classical republicans" who subordinated individual rights to the good of the community, in contrast to Lockean liberals who founded government on the protection of individual rights. See, e.g., DANIEl A. FARBER \& SUZANNA SHERRY, A HISTORY OF THE AMERICAN CONSTITUTION 11-13 (1990). As this passage indicates, however, these writers were in complete accord with Locke on the government's obligation to protect natural rights.

45. Blackstone, supra note 24. 
Blackstone's chapter on the king's duties began with Calvin's Case. It was "a maxim in the law," he observed, "that protection and subjection are reciprocal." 46 Following the prevailing eighteenth-century view, he identified these "reciprocal duties" with "the original contract between king and people," 47 the violation of which by James II had led to the Glorious Revolution.

Blackstone set the doctrine of reciprocal allegiance and protection in the broader framework of social contract theory. Although he denied the historical reality of a state of nature or a formal compact, he maintained that there was an "original contract of society ... [that] in nature and reason must always be understood and implied, in the very act of associating together." 48 This contract provided:

[T] hat the whole should protect all its parts, and that every part should pay obedience to the will of the whole, or, in other words, that the community should guard the rights of each individual member, and that (in return for this protection) each individual should submit to the laws of the community; without which submission of all it was impossible that protection should be certainly extended to any. ${ }^{49}$

In this formulation, Blackstone combined the three strands of English constitutional thought that we have considered.

A close reading of Blackstone reveals the structure of classical thought on the positive and negative character of individual rights and duties. In a state of nature, an individual has a right to be free from interference by others. In this sense, natural liberty is negative. ${ }^{50}$ According to social contract theory, however, society is formed to obtain the advantages of association with others. ${ }^{51}$ In contrast to natural liberty, the benefits of society are positive in character. ${ }^{52}$ One of the

46. Id. at *233 (citing Calvin's Case, 7 Co. Rep. 1a, 5a, 77 Eng. Rep. 377, 382 (1608)); see also id. at *123 ("Allegiance is the right of the magistrate, and protection the right of the people.").

47. Id. at $* 233$.

48. Id. at $* 47-48$.

49. Id. at *48.

50. For a fuller discussion of the classical conception of liberty, which contained both positive and negative elements, see infra Part I(C).

51. See, e.g., 1 BlAckstonE, supra note 24 , at $* 45, * 47-48$.

52. It is important to distinguish two meanings of the term "positive." In one sense, it is opposed to "negative." A positive right or liberty is a right to act in a particular way, or to receive or possess a particular thing, whereas a negative right or liberty is a right to be free from interference or coercion. For contemporary accounts of the relationship between positive and negative liberty, see ISAIAH BERLIN, Two Concepts of Liberty, in FouR ESSAYS ON LIBERTY 118 (1969); LIBERTY (David Miller ed., 1991); Robin L. West, Reconstructing Liberty, 59 TENN. L. REV. (forthcoming 1992).

In a second sense, "positive" is contrasted with "natural." A positive right is one that derives from the positive law of the state as distinguished from the law of nature.

The right to protection was a positive right in the first sense. Whether it also can be called a positive right in the second sense is somewhat more complex. For Coke, the right to protection was 
principal benefits is the protection of one's rights by the community. ${ }^{53}$ Protection is a positive right-a claim on the community to provide something to which the individual is entitled.

In return for the benefits of society, the individual assumes certain positive duties, which are summed up in the obligation of allegiance or obedience. These duties, Blackstone writes, require simply that the individual "contribute, on his part, to the subsistence and peace of the society." 54 Among other things, the citizen is obligated to pay taxes, ${ }^{55}$ to aid in enforcing the laws, ${ }^{56}$ and to defend the community against rebellion or invasion. ${ }^{57}$ In this sense, the obligation of protection runs both ways: The subject not only has a right to protection from the community, but also has a duty to contribute to the protection of other citizens and the

a natural right, arising from the natural bond between king and subject. For Locke and American writers, on the other hand, the right to protection derived not from the law of nature but from the social contract. In this sense, the right to protection was a positive rather than a natural right. $C f .1$ ANNALS OF CONG. 437 (Joseph Gales ed., 1789) (remarks of Rep. Madison) (distinguishing between natural rights and "positive rights ... [that result] from the social compact which regulates the action of the community, but which [are] as essential to secure the liberty of the people as any of the pre-existent rights of nature"), reprinted in CREATING THE BILL OF RIGHTS 81 (Helen E. Veit et al. eds., 1991). As Madison indicates, however, positive rights of this kind were fundamental rights deriving not from positive law enacted by the legislature, but from the social contract itself. Thus, they were not "merely" positive in the sense that they were granted-and thus could be limited or denied-by the legislature.

The central issue in DeShaney, of course, relates to constitutional protection for positive as opposed to negative rights and liberties. In this Article, I shall use the term "positive" in that sense (except where referring to "positive law").

53. As Blackstone expressed it:

[T] he principal aim of society is to protect individuals in the enjoyment of those absolute rights, which were vested in them by the immutable laws of nature, but which could not be preserved in peace without that mutual assistance and intercourse which is gained by the institution of friendly and social communities.

1 BLACKSTONE, supra note 24 , at $* 124$.

54. Id. at $* 45$ (describing the duties of the individual regarded as a citizen).

55. Blackstone characterized taxes as "a portion which each subject contributes of his property, in order to secure the remainder." Id. at *281; see also id. at *307 (same). Locke explained the need for taxation in similar terms. See LockE, supra note $25, \S 140$.

56. For example, at common law, an individual who had knowledge that a felony had been committed had the legal duty to inform the authorities as soon as possible; failure to do so made the individual guilty of misprision of felony. 4 BLACKSTONE, supra note 24 , at *121. In addition, every person who was present when a felony was committed had the legal duty to arrest the offender. Id. at "293. Individuals also were obligated to join the posse comitatus when requested to do so by an authorized officer. Id. at $* 122$; see also 1 id. at $* 343-44$.

57. See 4 id. at $* 122$. 
community itself. ${ }^{58}$ To put it another way, under the classical view, society is an association for mutual protection. ${ }^{59}$

The community fulfills its duty of protection through the making and enforcement of laws. According to Blackstone, the legislative power in a state has an obligation to enact laws for the protection of natural rights. ${ }^{60} \mathrm{He}$ implies, for example, that laws must be enacted against murder and theft. ${ }^{61}$ Such laws do not make these acts wrongful, but are merely declaratory of the law of nature, which forbids violations of the natural rights of individuals. ${ }^{62}$

The state's duty of protection requires not only the enactment of laws by the legislature, but also their enforcement by the executive and the courts. Under the English constitution, the executive power was

58. John Stuart Mill, although he rejected social contract theory, expressed the substance of this view in On Liberty:

[E]very one who receives the protection of society owes a return for the benefit, and the fact of living in society renders it indispensable that each should be bound to observe a certain line of conduct towards the rest. This conduct consists first, in not injuring the interests of one another; ... and secondly, in each person's bearing his share ... of the labours and sacrifices incurred for defending the society or its members from injury and molestation.

John S. MILL, ON LIBERTY 75 (Stefan Collini ed., 1989) (1859).

59. See LOCKE, supra note $25, \S 123$.

60. See 1 Blackstone, supra note 24 , at $* 52-53$ (stating that it is not merely the right, but the duty of the legislature to make laws for the direction of individuals); id. at *41 (arguing that all valid human laws derive their force and authority from the law of nature); id. at *124 ("[T]he first and primary end of human laws is to maintain and regulate these absolute rights of individuals.").

61. See id. at *42-43, *54. From Blackstone's perspective, the question is not whether the state must pass laws forbidding murder, but whether it may pass laws allowing it or requiring it. This difference in perspective is important for understanding the classical conception of the state.

According to Blackstone, the legislative power of society has not merely the right, but the duty to make laws:

For since the respective members are bound to conform themselves to the will of the state,

it is expedient that they receive directions from the state declaratory of that its will. ... [n]t

is therefore incumbent on the state to establish general rules, for the perpetual information

and direction of all persons in all points, whether of positive or negative duty.

Id. at *52-53. Thus, the state's law is comprehensive in nature; in principle it contains directions with respect to all situations. Because the law is comprehensive, it cannot remain neutral with respect to the legality of an act, but must take a position either forbidding, allowing, or requiring it. In the case of murder, for example, the state's law, if it is to conform with natural law, must declare that act to be a crime. If it does not enact such a law, the state in effect has provided that murder is allowed.

This interpretation helps to explain Blackstone's statement that a human law would violate natural law if it "should allow or enjoin us to commit" murder. Id. at *43 (emphasis added). To a modern reader, the reference to a law "allow[ing]" the commission of murder seems odd. Under the conception of state action that prevails today-and that underlies the position taken by Judge Posner and Chief Justice Rehnquist in DeShaney-a state that failed to legislate against murder would have taken no action at all, but simply failed to intervene to prevent private conduct. Under the classical view, however, the state's failure to prohibit murder would, in effect, have allowed it, in contravention of the law of nature.

62. See id. at $* 42-43, * 54$. 
vested in the king. ${ }^{63}$ The function of the king as supreme executive was "to protect the community, and each individual therein, from every degree of injurious violence, by executing those laws which the people themselves ... have consented to." 64

To a large extent, the king enforces the laws through his courts. ${ }^{65}$ Courts of justice, according to Blackstone, are instituted "[t] he more effectually to accomplish the redress of private injuries, ... in order to protect the weak from the insults of the stronger, by expounding and enforcing those laws, by which rights are defined, and wrongs are prohibited."66 Blackstone stresses that the state, through its courts, has a duty to dispense justice to individuals; the administration of justice is a matter not of discretion, but of right. ${ }^{67}$

As the above discussion suggests, there is an important connection between the duty of protection and two other central doctrines of classical liberal thought: the rule of law and the separation of powers. The rule of law implies, among other things, that the rights of individuals are not dependent for their protection upon the arbitrary will of the government, but are recognized and protected by law. The legislature has a duty to enact laws for the protection of individual rights, the executive has a duty to enforce them, and the courts have a duty to apply them.

\section{B. The Right to Protection in Early American Constitutionalism}

American thought during the Revolutionary era was deeply influenced by all of these sources-the common law tradition of Coke and Blackstone, the history of English constitutionalism and the Glorious

63. Id. at $\approx 190$.

64. 4 id. at $* 127$.

65. See 3 id. at *23-24 ("[C]ourts of justice... are the medium by which [the king] administers the laws.").

66. Id. at $* 2$.

67. See, e.g., 1 id. at *141; id. at *266 ("Justice is not derived from the king, as from his free gift, but he is the steward of the public, to dispense it to whom it is due."); 3 id. at *115 (The king is "officially bound to redress in the ordinary forms of law" wrongs committed between subjects.).

This classical conception of the administration of justice should be contrasted with the legal positivist view that became predominant in the late nineteenth century. One of the leading exponents of this view, Thomas M. Cooley (who himself was an editor and thoughtful critic of Blackstone's Commentaries), wrote as follows:

[D]oing justice as between particular individuals, when they have a controversy before [a court], is not the end and object which were in view when [the] court was created .... Courts are created on public grounds; they are to do justice as between suitors, to the end that peace and order may prevail in the political society, and that rights may be protected and preserved. The duty is public: the individual advantage or loss results from the proper and thorough or improper and imperfect performance of a duty for which his controversy is only an occasion.

Thomas M. COOley, A TREatise on the LaW OF TORTS OR the Wrongs Which ARISE INDEPENDENTLY OF CONTRACT *379 (1st ed. 1879). 
Revolution, and the natural rights theory of Locke's Second Treatise. ${ }^{68}$ What integrated all these sources into a coherent worldview for Americans, as Bernard Bailyn and Gordon Wood have shown, was radical Whig ideology. ${ }^{69}$ As we have seen, it was a basic tenet of Whig ideology that protection was a primary purpose of government. ${ }^{70}$

In this way, the concept of protection became a fundamental principle of American constitutionalism. It played an important role in the Revolutionary controversy, and became a basic element of the newly formed governments.

1. The Revolution. The decision in Calvin's Case played an important role in the controversy between Americans and Great Britain leading up to the Revolution. The decision was relevant not only for its formulation of the relationship between subject and sovereign, but also because of the concrete issues that gave rise to that formulation.

The immediate issue in Calvin's Case was the status under English law of Scots born after the accession of James I of England, who already was King of Scotland. Coke held that as subjects of the same king, Scots were entitled to the same protection as his English subjects, and therefore were entitled to all the rights of subjects under English law, including the right to hold property. At the same time, however, Coke recognized that although they shared an allegiance to the same king, England and Scotland were separate realms, with separate parliaments and laws. ${ }^{71}$

Confronted with assertions of the absolute supremacy of Parliament over the colonies, Americans struggled during the decade before 1776 to define their status and rights within the British Empire. Gradually, they came to the view that their position was analogous to that of Scotland at the time Calvin's Case was decided. Following Coke's analysis of Scotland, they argued that the colonies were united to Great Britain only through their shared allegiance to a common king. Thus, Americans were not subject to the authority of Parliament at all, but only to their own legislatures and King George III. ${ }^{72}$

In this way, Coke's doctrine of reciprocal obligations came to the forefront of American constitutional thought. "The colonists," wrote James Wilson in an influential pamphlet, "ought to be dependent on the king, because they have hitherto enjoyed, and still continue to enjoy, his protection. . . . [O]bedience is founded on the protection derived from

\footnotetext{
68. See BAILYN, supra note 43 , at 22-54; Wood, supra note 24 , at 6-10.

69. See BAILYN, supra note 43, at 34; Wood, supra note 24, at 14-17.

70. See supra text accompanying note 44 .

71. See KETTNER, supra note 17 , at 13-28.

72. See id. at 131-72.
} 
government: for protection and allegiance are the reciprocal bonds, which connect the prince and his subjects."73

Although they adopted Coke's theory of the British Empire, Americans rejected his view that the bond between subjects and sovereign was natural and immutable. ${ }^{74}$ Instead, they described this relationship in terms of the original contract between king and people, in which the king was bound to protect the rights of his subjects in return for their allegiance. ${ }^{75}$

When Americans finally decided to break from Great Britain, they appealed to the precedent of the Glorious Revolution, in which James II was held to have "abdicated" government as a result of breaking the original contract. ${ }^{76}$ Thus, the Declaration of Independence, after reciting a long list of grievances that the king had failed to redress, alleged that the king "has abdicated Government here, by declaring us out of his Protection and waging War against us."77 Several state constitutions justified independence on the same ground. ${ }^{78}$

2. The First State Constitutions. After independence, Americans turned to the creation of new state governments. ${ }^{79}$ In this context, the traditional image of a bond between subjects and rulers lost much of its force. ${ }^{80}$ Instead, Americans viewed themselves as free citizens deliberating on the structure of their political life. In framing their new governments, they were strongly influenced by social contract theory. ${ }^{81}$

73. James Wilson, Considerations on the NATURe and Extent of the Legislative Authority of THE British Parlament (1774), reprinted in 2 The Works of JAMES Wilson 743 (Robert G. McCloskey ed., 1967). For another extensive discussion of the application of Calvin's Case to the Revolutionary controversy, see JoHN ADAMS, Novanglus IX (1774), reprinted in 4 THE Works OF JoHN AdAMS 141-51 (Charles Adams ed., 1851).

74. See KETTNER, supra note 17, at 165 .

75. See id. at 160-61, 165-67; WoOD, supra note 24, at 268-70.

76. See KeTtNer, supra note 17, at 169-71; GARRY Wills, INVENTING AMERICA: JEFFerSON'S DECLARATION OF INDEPENDENCE 52-55, 64 (1978); WOOD, supra note 24, at 270.

77. THE DECLARATION OF INDEPENDENCE para. 25 (U.S. 1776). In his draft of the Declaration, Jefferson had written "declaring us out of his allegiance \& protection." See WiLls, supra note 76 , at 376.

78. See N.J. CONST. of 1776, pmbl., reprinted in 6 STATE CONSTTTUTIONS, supra note 13, at 449-50; N.Y. CONST. of 1777, pmbl., reprinted in 7 STATE CONSTITUTIONS, supra note 13, at 169; N.C. CONST. of 1776, reprinted in 7 STATE CONSTITUTIONS, supra note 13, at 404; PA. CoNST. of 1776, reprinted in 8 STATE CONSTITUTIONS, supra note 13, at 277; S.C. CONST. of 1776, reprinted in STATE CONSTITUTIONS, supra note 13, at 464; VA. CONST. of 1776, reprinted in 10 STATE Const1TUTIONS, supra note 13 , at 52 .

79. On the making of the state constitutions, see generally WILLI P. ADAMS, THE FIRST AMERICAN CONSTITUTIONS (Rita Kimber \& Robert Kimber trans., 1980); Wood, supra note 24, at 125-255.

80. See Wood, supra note 24 , at $282-83,290$.

81. See ADAMS, supra note 79 , at $156-58$; WooD, supra note 24 , at $282-91$. 
Most of the first state constitutions included a bill of rights, ${ }^{82}$ which generally began by declaring the natural rights of mankind. For example, Virginia's Declaration of Rights, the first to be adopted, asserted:

That all men are by nature equally free and independent, and have certain inherent rights, of which, when they enter into a state of society, they cannot, by any compact, deprive or divest their posterity; namely, the enjoyment of life and liberty, with the means of acquiring and possessing property, and pursuing and obtaining happiness and safety. 83

This provision implied that society was founded on contract, a view that was made explicit in the Massachusetts Constitution of 1780:

The body-politic is formed by a voluntary association of individuals; it is a social compact by which the whole people covenants with each citizen and each citizen with the whole people that all shall be governed by certain laws for the common good ... ; that every man may, at all times, find his security in them. ${ }^{84}$

With its basis in such a compact, the function of government was to protect the natural rights of its citizens. Thus, several states declared that "government is, or ought to be, instituted for the common benefit, protection, and security of the people." 85 As we have seen, a number of states expressly recognized protection as the right of every individual. ${ }^{86}$ As the Massachusetts Constitution put it:

82. See CONN. CONST. ORDINANCE of 1776, art. I, reprinted in 2 STATE CONSTItutions, supra note 13, at 143-44; DEL. DeClaRATION OF RIGHTS of 1776, reprinted in 2 STATE CONSTITUTIONS, supra note 13, at 197-99; MD. DECLARATION OF RIGHrs of 1776, reprinted in 4 STATE CONSTITUTIONS, supra note 13, at 372-75; MASs. CONST. of 1780, pt. I, reprinted in 5 STATE CONSTITUTIONS, supra note 13, at 93-96; N.H. CONST. of 1784, pt. I, reprinted in 6 STATE CoNSTITUTIONS, supra note 13, at 344-47; N.C. CONST. of 1776, Declaration of Rights, reprinted in 7 STATE Constitutions, supra note 13, at 402-04; PA. CoNST. of 1776, Declaration of Rights, reprinted in 8 STATE CONSTITUTIONS, supra note 13, at 278-79; VA. DECLARATION OF RIGHTS of 1776, reprinted in 10 STATE CONSTITUTIONS, supra note 13 , at 48-50.

83. Va. Declaration of RightS $\S 1$, reprinted in 10 STATE CONSTITUTIONS, supra note 13 , at 49. For similar provisions, see MASs. CONST. of 1780 , pt. I, art. I, reprinted in 5 STATE CONSTITUTIONS, supra note 13, at 93; N.H. CONST. of 1784, pt. I, art. II, reprinted in 6 STATE CONSTITUTIONS, supra note 13, at 344; PA. CONST. of 1776, Declaration of Rights, art. I, reprinted in 8 STATE Constitutions, supra note 13 , at 278.

84. MASS. CONST. of 1780, pmbl, reprinted in 5 STATE CONSTITUTIONS, supra note 13, at 9293. The Massachusetts Constitution was drafted by John Adams. See ADAMS, supra note 79, at 92, 157. Adams's draft appears in 4 THE WoRks OF JOHN ADAMS, supra note 73, at 219-67.

85. VA. Declaration of Rights $\S 3$, reprinted in 10 State Constitutions, supra note 13 , at 49. For similar provisions, see MAss. CoNST. of 1780, pt. I, art. VII, reprinted in 5 STATE CONSTITUTIONS, supra note 13, at 94; N.H. CoNST. of 1784, pt. I, art. X, reprinted in 6 STATE CONSTITUTIONs, supra note 13, at 345; PA. CONST. of 1776, Declaration of Rights, art. V, reprinted in 8 STATE Constitutions, supra note 13, at 278; R.I. Declaration of Rights of 1776, $\S 2$, reprinted in 8 STATE CONSTITUTIONS, supra note 13, at 387; VT. CONST. of 1777, pmbl., reprinted in 9 STATE Constrrutions, supra note 13, at 487.

86. See supra text accompanying notes 13-14. 
Each individual of the society has a right to be protected by it in the enjoyment of his life, liberty, and property, according to standing laws. He is obliged, consequently, to contribute his share to the expense of this protection; to give his personal service, or an equivalent, when necessary; but no part of the property of any individual can, with justice, be taken from him, or applied to public uses, without his own consent, or that of the representative body of the people. ${ }^{87}$

This provision articulates the essence of the classical eighteenth-century doctrine of the right to protection. Every individual has a positive right to protection by society. This protection is afforded by the enactment and execution of laws for the security of life, liberty, and property. ${ }^{88}$ In return for this protection, the individual owes positive duties to society. $\mathrm{He}$ is obliged to pay taxes to meet the expense of protectionwith the Lockean reservation, however, that he may not be taxed without his consent or that of his representatives. ${ }^{89}$ In addition, where necessary he must render personal service in defense of the community. ${ }^{90}$

3. The Federal Constitution. The view that government was formed to protect the life, liberty, and property of its citizens was fully shared by the Framers of the Federal Constitution. ${ }^{91}$ As James Madison wrote in The Federalist, the "protection" of "the faculties of men," and of "the rights of property" to which these faculties give rise, "is the first object of government."92 The advocates of the Constitution argued, among other things, that the rights of citizens would enjoy greater security under the proposed Constitution than under the Confederation. ${ }^{93}$ at 94.

87. MASS. CONST. of 1780 , pt. I, art. X, reprinted in 5 STATE CONSTITUTIONS, supra note 13,

88. In addition to article $X$, quoted in text, see the preamble to the Massachusetts Constitution: "It is the duty of the people, ... in framing a constitution of government, to provide for an equitable mode of making laws, as well as for an impartial interpretation and a faithful execution of them; that every man may, at all times, find his security in them." Id. pmbl., reprinted in 5 STATE CoNSTITUTIONS, supra note 13 , at 93.

89. See Locke, supra note $25, \S 140$.

90. This point is expressed most clearly in the New York Constitution: "[I]t is the duty of every man who enjoys the protection of society to be prepared and willing to defend it." N.Y. CONST. of 1777, art. XL, reprinted in 7 STATE CONSTITUTIONS, supra note 13, at 179.

91. See generally Jennifer Nedelsky, Private Property and the Limits of American CONSTTTUTIONALISM (1990).

92. The Federalist No. 10, at 42 (James Madison) (Max Beloff ed., 2d ed. 1987). (All further citations to the Federalist will be to this edition.) For an excellent discussion of The Federalist, see David F. Epstein, The Political Theory of the Federalist (1984).

93. See, e.g., The Federalist No. 51, at 267 (James Madison). In the fifty-first Federalist, for example, Madison argued in favor of establishing "the extended republic of the United States" by means of an analogy to the state of nature and the social compact:

Justice is the end of government. It is the end of civil society. . . In a society, under the forms of which the stronger faction can readily unite and oppress the weaker, anarchy may as truly be said to reign, as in a state of nature where the weaker individual is not secured against the violence of the stronger: And as in the latter state even the stronger individuals 
Under the Constitution, the function of protection was divided between the federal government, which was to serve "general and national purposes," and the states, which retained authority over local affairs. ${ }^{94}$ Thus, the national government was responsible for security against foreign danger. ${ }^{95}$ In addition, the United States was obligated under the Constitution to "protect each of [the states] against Invasion; and on Application of the Legislature . . against domestic Violence."96 The states, on the other hand, were to retain their role as "the immediate and visible guardian[s] of life and property," a role that they performed through "the ordinary administration of civil and criminal justice."97 Thus, Madison wrote, the powers reserved to the states extended "to all the objects, which, in the ordinary course of affairs, concern the lives, liberties, and properties of the people." 98

In this light, it is hardly surprising that the federal Bill of Rights contained no guarantee of a right to protection similar to those found in the state constitutions. 99 The Bill of Rights, which was added to the Constitution largely in response to opponents' fears of arbitrary federal power, imposed restrictions only on the federal government. ${ }^{100}$ Under the Constitution, however, it was the states, not the federal government, which were to provide general protection of life, liberty, and property.

are prompted by the uncertainty of their condition, to submit to a government, which may protect the weak as well as themselves: so in the former state, will the more powerful factions be gradually induced by a like motive to wish for a government which will protect all parties, the weaker as well as the more powerful.

Id. at 267-68.

It should be observed that in this passage, Madison treats the oppression of faction as essentially a sort of private domination-domination by a group for the sake of its own private interest, even though a faction that constitutes a majority may accomplish that domination under the forms of republican government. He argues that the end of civil society requires that government be constructed in such a way as to protect against such domination. Similarly, Locke wrote that government was established to enact rules to "moderate the Dominion of every Part and Member of the Society." LOCKE, supra note $25, \S 222$.

94. The Federalist No. 3, at 9 (John Jay); see also The Federalist No. 10, supra note 92, at 46.

95. The Federalist No. 45, at 234 (James Madison); see also The Federalist No. 3, supra note 94; THE Federalist No. 41, at 204 (James Madison) (referring to "[s]ecurity against foreign danger" as "one of the primitive objects of civil society" and "an avowed and essential object of the American Union").

96. U.S. CoNST. art. IV, § 4.

97. The Federalist No. 17, at 80 (Alexander Hamilton).

98. The Federalist No. 45, supra note 95, at 238.

99. See supra text accompanying notes $85-87$ (discussing state constitutional provisions). As we shall see, however, the Due Process Clause of the Fifth Amendment can be interpreted to recognize a right to protection within the sphere of the federal government. See infra text accompanying notes 333-65.

100. For accounts of the framing of the Bill of Rights, see FARBER \& SHERRY, supra note 44, at 219-45; Robert A. Rutland, The Birth OF THe Bill of Rights, 1776-1791 (1955). 
Thus, it would have made no sense for the Bill of Rights to recognize a general right to protection by the federal government.

It would have been possible, on the other hand, for the Constitution to have guaranteed a right to protection by the states. The original Constitution, however, imposed few restrictions on the states. ${ }^{101}$ Although most of these restrictions were calculated to prevent state interference with the national objects committed to Congress, others related to individual rights. In addition to such negative rights as the safeguards against bills of attainder and ex post facto laws, ${ }^{102}$ the Constitution secured certain positive rights to protection by the states. Two such rights were of particular importance. First, the ban on state laws "impairing the Obligation of Contracts" 103 implied that the states had a duty to enforce the lawful rights of creditors. ${ }^{104}$ Second, the Comity Clause provided that "[t]he Citizens of each State shall be entitled to all Privileges and Immunities of Citizens in the several States." 105 The basic purpose of this provision was to require that a citizen of one state be accorded rights of citizenship when traveling or residing in other states. As we shall see, the courts interpreted this provision to include the right to protection by state government-an understanding that was later incorporated into the Privileges or Immunities Clause of the Fourteenth Amendment. ${ }^{106}$

Apart from these limited provisions, the original Constitution did not protect individual rights-negative or positive-in relation to the states. Instead, the founders apparently assumed that the states could be relied upon to protect adequately the rights of their citizens. As we shall see, the mid-nineteenth-century conflicts over slavery and civil rights led the Framers of the Fourteenth Amendment to reject this assumption, and to incorporate a right to protection by state government into the Federal Constitution.

\section{Protection and Liberty}

The right to protection was informed by the classical conception of liberty. Contrary to Posner's view, this conception was not merely one of

101. These restrictions are primarily found in Article I, Section 10.

102. U.S. CoNST. art. I, $\S 10$, cl. 1.

103. Id.

104. On the affirmative obligation imposed by the contract clause, see David P. Currie, Positive and Negative Constitutional Rights, 53 U. CHI. L. REV. 864, 874-75 (1986). For a summary of antebellum contract-clause jurisprudence, see THOMAS M. COOLEY, A TREATISE ON THE CONSTItUtional Limitations Which Rest upon the Legislative POWER OF the States of the AMERICAN UNION *273-94 (1868 \& photo. reprint 1972).

105. U.S. CoNST. art. IV, $\S 2$, cl. 1.

106. See infra text accompanying notes $316-32$. 
negative liberty, but had an important positive dimension-the protection of individual rights under law. ${ }^{107}$

Blackstone's account once more provides the best starting point for analysis. ${ }^{108}$ Following Locke, Blackstone begins with "natural liberty"-the freedom that would be enjoyed by individuals in a state of nature. He defines natural liberty as "a power of acting as one thinks fit, without any restraint or control, unless by the law of nature."109

This conception of natural liberty contains both positive and negative elements. The first branch of the definition is positive: "a power of acting as one thinks fit." Liberty is not merely a lack of constraint, but a power-the capacity to act according to one's own reason and free choice." In this sense, liberty means "Self-determination" or "Selfdirection."111

In a state of nature, the individual possesses the power to act "without any restraint or control."112 It is true, as Blackstone adds, that this liberty is limited by "the law of nature."113 But that law, lacking effective means of enforcement outside civil society, is a matter more of internal guidance than of external constraint. ${ }^{114}$ In this respect, natural liberty comes close to being a pure form of negative freedom.

107. On the distinction between negative and positive rights and liberties, see supra note 52. For a valuable account of the eighteenth-century conception of liberty, see JOHN P. REID, THE CONCEPT OF LIBERTY IN THE AGE OF THE AMERICAN REVOLUTION (1988). Reid properly emphasizes the importance of common law ideas, but underrates the role of natural rights in eighteenth-century thought.

108. Blackstone's account of liberty is of particular importance for several reasons: it was representative of much contemporary thought, see REID, supra note 107; it had great influence on the conception of liberty within the legal tradition prior to the Civil War; and it was relied upon during the congressional debates leading to the adoption of the Fourteenth Amendment, see infra text accompanying note 254-55. $\S 4$.

109. 1 BLACKSTONE, supra note 24 , at $* 125$. For a similar definition, see LoCKE, supra note 25 ,

110. On the eighteenth-century definition of liberty in terms of power, see WooD, supra note 24, at 21-23. For example, in Cato's Letters, Trenchard and Gordon defined liberty as "the Power which every Man has over his own Actions, and his Right to enjoy the Fruits of his Labour, Art, and Industry." CATO's LetTERs No. 62, supra note 44, at 244. For the philosophical basis of this view, see John LOCKe, AN ESSAY CONCERNINg Human Understanding bk. II, ch. XXI (Peter H. Nidditch ed., 1975).

111. Richard Price, Observations on the Nature of Civil Liberty 3 (London, 1776). As Price makes clear, liberty in classical liberal thought is an attribute of the individual considered as an actor, not merely as the passive object of action by others. See id. (By natural or "physical" liberty, "I mean that principle of ... Self-determination, which constitutes us Agents; or which gives us a command over our actions."); see also LOCKE, supra note $25, \$ \S 57-59$ (discussing liberty of individual as "a free and intelligent Agent"). Self-determination is at the root of the positive concept of liberty. See BERLIN, supra note 52, at 131.

112. 1 Blackstone, supra note 24 , at $* 125$.

113. Id.

114. See id. at *39-41,*125; see also LockE, supra note $25, \S 136$. 
Such unrestrained liberty, however, is self-destructive: If no one is subject to any external restraints, then no one can have any security against the invasion of his liberty by others. ${ }^{115}$ Thus, to secure their liberty and to obtain the other benefits of social life, individuals enter into society and agree to obey its laws. In so doing, they give up a part of their natural liberty - the unrestrained right to act as they think fit-but gain something more valuable: "civil liberty," which is the liberty that belongs to individuals as members of society. 116

Blackstone defines civil liberty as "natural liberty so far restrained by human laws (and no farther) as is necessary and expedient for the general advantage of the public."117 Again, this conception of civil liberty has both negative and positive elements. ${ }^{118}$

In its negative aspect, civil liberty requires that individuals be left free from state control except where necessary for the public good. Blackstone condemns "every wanton and causeless restraint of the will of the subject" as "a degree of tyranny" and "destructive of liberty."119 Much of Blackstone's chapter on "the absolute rights of individuals" is devoted to English constitutional protections against governmental oppression, such as the writ of habeas corpus. ${ }^{120}$ Similarly, much of Chancellor James Kent's corresponding discussion relates to the provisions of the American bills of rights that protect individual rights against the government. ${ }^{121}$ This is the negative liberty that Posner emphasizes.

There was, however, a positive element in the concept of civil liberty that was no less essential. For the principal justification of legal restraints on conduct was to protect the rights of members of society.

115. See 1 BLACKSTONE, supra note 24 , at $* 125$.

116. Id. For a similar account of natural and civil liberty, see JAMES WILSON, Speech Delivered on 26th November, 1787, in the Convention of Pennsylvania, in 2 THE WORKS OF JAMES WILSON, supra note 73 , at $765,767$.

Civil liberty was sometimes referred to by Blackstone and others as "political liberty." This term, however, soon came to mean the right to share in political power, especially in America. See infra text accompanying notes 129-30.

117. 1 BLACKSTONE, supra note 24 , at *123 (citing J. INST. 1.3.1). For a similar view, see MONTESQuieu, The SpIRIT OF THE Laws pt. 2, bk. 11, ch. 3, at 155 (Anne M. Cohler et al. trans. \& eds., 1989).

118. Although Blackstone does not do so, one might distinguish between private civil liberty (the individual's liberty in relation to other individuals in civil society) and public civil liberty (his liberty in relation to the state). Private civil liberty includes the same elements as natural liberty, modified by civil society. In a positive sense, it means the power to act as one thinks fit, within the bounds of civil law; in a negative sense, it means freedom from all restraints not authorized by that law. See LOCKE, supra note $25, \S 22$. In the following two paragraphs, I discuss the classical conception of public civil liberty.

119. 1 BLACKSTONE, supra note 24 , at $* 126$.

120. See id. at *122-44.

121. See 2 James Kent, Commentaries on AMERICAN LAw *1-37 (1826). 
Thus, Blackstone argues, "the law, which restrains a man from doing mischief to his fellow-citizens, though it diminishes the natural, increases the civil liberty of mankind."122 From this positive perspective, it may be said that "civil liberty, rightly understood, consists in protecting the rights of individuals by the united force of society."123 Used in this way, liberty is virtually synonymous with protection. ${ }^{124}$

Thus, in contrast to a negative conception of liberty, which perceives law solely as a limitation on individual freedom, classical liberalism regarded law as essential to liberty. ${ }^{125}$ As Locke wrote: "Liberty is to be free from restraint and violence from others which cannot be, where there is no Law"; thus, "however it may be mistaken, the end of Law is not to abolish or restrain, but to preserve and enlarge Freedom." 126

Incorporating both the negative and the positive elements of civil liberty, Blackstone describes rights under the English constitution as "either that residuum of natural liberty, which is not required by the laws of society to be sacrificed to public convenience; or else those civil privileges, which society hath engaged to provide, in lieu of the natural liberties so given up by individuals." 127

122. 1 BLACKSTONE, supra note 24 , at $* 125-26$.

123. Id. at *251. Similarly, the author of a British pamphlet asserted that "[t]rue political Liberty consists in the protection, safety, and defence of every one in the peaceable enjoyment of his own rights, guarantee'd and secured to him by the laws, to which a full and exact obedience and submission are due." CIVIL LIBERTY ASSERTED 30-31 (London, 1776), quoted in REID, supra note 107, at 68.

124. For other examples of this usage, see 1 BLACxsTone, supra note 24 , at *424 (Because slavery is not recognized by English law, "the instant [a slave] lands in England, [he] becomes a freeman; that is, the law will protect him in the enjoyment of his person, and his property.") (emphasis added); id. at *425 (The law of England "gives liberty, rightly understood, that is, protection" to all persons irrespective of religion.) (emphasis added).

A closely related usage identified liberty with security. See, e.g., ReID, supra note 107, at 68-71; Woon, supra note 24, at 609 \& n.22. As Montesquieu expressed it, political or civil liberty is "that tranquility of spirit which comes from the opinion each one has of his security, and in order for him to have this liberty the government must be such that one citizen cannot fear another citizen." MONTESQUIEU, supra note 117, pt. 2, bk. 11, ch. 6, at 157.

125. See REID, supra note 107, ch. 8; see also ADAMS, supra note 79, at 159-60; ForREST MCDonald, Novus Ordo Seclorum: The INTEllectual ORIgins of The Constitution 159-60 (1985).

126. LockE, supra note $25, \S 57$.

127. 1 BlackstoNe, supra note 24 , at *129. As Michael Kent Curtis has suggested, this conception of constitutional liberty as including both the privileges of society and a residuum of natural liberty appears to be one precursor of the term "privileges or immunities," a concept that has a central place in the Fourteenth Amendment. See Michael K. Curtis, No State Shall Abridge: The Fourteenth AMENDMENT AND the Bill of Rights 64 (1986). For further discussion of privileges and immunities, see infra text accompanying notes 316-32. 
Americans accepted the classical definition of civil liberty as natural liberty bounded and protected by law. ${ }^{128}$ In addition, they emphasized a third sort of freedom, often referred to as political liberty: the right to participate in self-government, in making the laws by which one was ruled. ${ }^{129}$ As the Delaware Declaration of Rights expressed it, "the Right in the People to participate in the Legislature, is the Foundation of Liberty and of all free Government."130 Political liberty constituted the right to self-determination of the community as a whole.

Articulating the American view in 1826, Kent wrote that civil liberty "consists in being protected and governed by laws made ... by the representatives of the people, and conducive to the general welfare."131 Thus, explained Francis Lieber, civil liberty meant "not only the absence of individual restraint"; instead, "when the term Civil Liberty is used, there is now always meant a high degree of mutually guaranteed protection against interference with [important] interests and rights ... together with an effectual share in the making and administration of the laws as the best apparatus to secure that protection."132

\section{The Legal Meaning of Protection}

As I have shown above, the right to protection was a central principle of Anglo-American constitutionalism prior to the Civil War. This right was not merely a matter of constitutional theory, but was a concrete legal concept.

This Part explores the concept of protection in the classical legal tradition. That concept had three major elements. The first related to the status of the individual: To be under the protection of the law meant

128. See, e.g., BAILYN, supra note 43, at 77; MCDonald, supra note 125, at 159-60; REID, supra note 107, at 61. For an excellent account of the American view of liberty and protection, in some respects similar to the account presented here, see Philip A. Hamburger, Equal Protection and Equal Civil Rights in Eighteenth Century America (unpublished manuscript) (Part I: The State-ofNature Analysis and the Idea of Protection).

129. See ADAMS, supra note 79, at 156-57; WooD, supra note 24, at 24-25; Gordon S. Wood, Classical Republicanism and the American Revolution, 66 CHI.-KENT L. REV. 13, 23 (1990).

130. Del. Declaration of Rights of 1776, art. 6, reprinted in 2 STATE Constitutions, supra note 13, at 198; see also MD. CoNST. of 1776, Declaration of Rights, art. V, reprinted in 4 STATE Constitutions, supra note 13, at 373; ADAMS, supra note 79, at 157.

131. 2 KENT, supra note 121 , at *1.

132. Francis Lieber, Civil Liberty and Self-Government 24 (2d ed. 1859). For a late nineteenth-century expression of the same view, see Thomas M. CoOley, The General PrinciPLES OF CONSTTTUTIONAL LAW (1880):

Civil liberty may be defined as that condition in which rights are established and protected, by means of such limitations and restraints upon the action of individual members of the political society as are needed to prevent what would be injurious to other individuals, or prejudicial to the general welfare.

Id. at 226. 
to have the status of a freeman and a citizen. A second aspect referred to substantive rights: Protection meant that the law recognized and secured an individual's rights to life, liberty, and property. Finally, the most basic meaning of protection referred to the enforcement of rights: the specific ways in which government prevented violations of substantive rights, or redressed and punished such violations.

\section{A. The Status of Freeman and Citizen}

As we have seen, the classical tradition identified liberty with protection. ${ }^{133}$ In one sense, therefore, to be under the protection of the law meant to be a free person, one whose rights were recognized by the law. In relation to the state, it meant to be a subject or, in a republic, a citizen-a person entitled to protection as a member of the political community. In this way, the concept of protection was closely related to the ideas of legal personality and citizenship. ${ }^{134}$

In the classical tradition, the opposite of a free person was a slave. Slavery was both a political and a legal concept. As John Phillip Reid has explained, slavery in a political sense meant arbitrary government and "the absence of [the rule of] law: law that protected the individual and law that limited the authority of both private masters and public rulers." 135

In a legal sense, slavery was subjection to the absolute power of a master, without protection under the law; slaves were regarded "as things or property, rather than persons." ${ }^{136}$ In Somerset's Case, ${ }^{137}$ Lord Mansfield declared that slavery was "so odious" that "it is incapable of being introduced on any reasons, moral or political; but only [by] positive law," and held that slavery was not recognized by the law of England. ${ }^{138}$ For this reason, Blackstone wrote, "the instant [a slave] lands in England, [he] becomes a freeman; that is, the law will protect him in the enjoyment of his person, and his property." 139

Slavery, of course, continued to exist by positive law in much of the United States. As Jacobus tenBroek and William Wiecek have shown,

133. See supra Part $\mathrm{I}(\mathrm{C})$.

134. On the relation between protection and citizenship, see generally KETTNER, supra note 17.

135. REID, supra note 107, at 48 . On the political concept of slavery, see id. at 38-54; BAILYN, supra note 43 , at $232-46$.

136. 1 BLACKSTONE, supra note 24 , at *423-24; see also $2 \mathrm{KENT}$, supra note 121 , at $* 253$.

137. Somerset v. Stewart, Loftt 1, 98 Eng. Rep. 499 (K.B. 1772).

138. Id. at 19, 98 Eng. Rep. at 510. On Somerset's Case and its importance in American law, see William M. WiECEK, THE SOURCES OF ANTISLAVERY CONSTITUTIONALISM IN AMERICA, 17601848, at 28-45 (1977).

139. 1 BLACKSTONE, supra note 24 , at *424; see also 2 KENT, supra note 121 , at *248-49. 
the right to protection became a central concept in anti-slavery constitutionalism prior to the Civil War. ${ }^{140}$ As we shall see, extending the protection of the law to the former slaves was one of the principal objects of the Fourteenth Amendment. ${ }^{141}$

\section{B. Recognition of Substantive Rights}

To enjoy the status of a freeman and a citizen implied that one's rights were recognized. This leads to the second basic aspect of "protection": the recognition of substantive rights by the law. The law protected rights in this sense by declaring that persons had certain rights and directing that those rights be observed. ${ }^{142}$

The classical legal tradition distinguished between two sorts of substantive rights: "absolute" and "relative." Absolute rights were those that would belong to individuals in a state of nature. ${ }^{143}$ By contrast, relative rights were those that were "incident to [persons] as members of society, and standing in various relations to each other."144 Blackstone declared that "the first and primary end of human laws" was "to protect individuals in the enjoyment of [their] absolute rights"; the protection of relative rights was a secondary aim. ${ }^{145}$

The classical tradition identified the absolute rights of individuals as the rights of personal security, personal liberty, and private property. ${ }^{146}$ Personal security was defined as "a person's legal and uninterrupted enjoyment of his life, his limbs, his body, his health, and his reputation." 147 Personal liberty was the power of moving "without imprisonment or restraint, unless by due course of law."148 Finally, the right of private property consisted of "the free use, enjoyment, and disposal of all [one's] acquisitions, without any control or diminution, save only by the laws of the land." 149 Taken together, these three absolute rights were often referred to as "security of person and property."

140. See TENBROEK, supra note 10 , at 51-54, 117-20; WIECEK, supra note 138 , at 155-56, 267 70, 275.

141. See infra Part III.

142. See 1 Blackstone, supra note 24 , at $* 54-55$.

143. See id. at *123-24.

144. Id. at *123. For example, personal liberty was an absolute right, whereas the relationship of master and servant gave rise to relative rights. See id. at $* 134,422$.

145. Id. at $* 124-25$.

146. Id. at *129; 2 KENT, supra note 121 , at $* 1$.

147. 1 BLACKSTONE, supra note 24, at *129. American writers added such rights as freedom of religion and freedom of opinion to the category of absolute rights. See, e.g., id. at *129 n.6 (Tucker ed. note); 2 KENT, supra note 121 , at $\$ 34-37$.

148. 1 BLACKSTONE, supra note 24 , at $* 134$.

149. Id. at $* 138$. 
To understand the classical notion of absolute rights, it is essential to recognize that "absolute" had a different meaning than it does in modern usage. In classical terminology, an absolute right was one that was inherent in the individual as such, and not derived from his relations as a member of society. ${ }^{150}$ To say that a right was absolute, however, did not mean that it could never be restricted. Instead, absolute rights were subject to regulation for the public good, especially to protect the rights of others. ${ }^{151}$ In other words, although absolute rights had their origin in nature, they were defined in terms of civil rather than natural liberty. ${ }^{152}$

As elements of civil liberty, absolute rights were not merely natural rights but legal rights-rights protected by law. This was reflected in Blackstone's definitions of the absolute rights. Personal security, for example, was defined not merely as a negative right against invasion of one's life and person, but as a positive right to "legal and uninterrupted enjoyment" of these interests. ${ }^{153}$ Absolute rights were rights to the security of person and property; and this security was provided by law, whose end was the protection of rights.

Absolute rights were understood to apply not only against governmental oppression, but also against private violence. ${ }^{154}$ This is clear from the fact that these rights originate in the state of nature, where there is no government. ${ }^{155}$ Individuals enter society to secure their rights against private violence. ${ }^{156}$ Accordingly, when Blackstone and Kent discussed the ways in which the law protected absolute rights, ${ }^{157}$ they reviewed not only the barriers against governmental oppression contained in Magna Carta and the American bills of rights, but also the protections against private aggression afforded by civil and criminal law. ${ }^{158}$

150. See id. at *123-25; 2 KENT, supre note 121 , at $* 1$.

151. As Blackstone indicated, liberty and property might be limited by "due course of law" or "the laws of the land." 1 BLACKSTONE, supra note 24 , at *134,*138. Even the right to life might be forfeited by the violation of laws enforced by capital punishment. Id. at *133.

152. See supra Part I(C) (discussing natural and civil liberty).

153. 1 BlACKSTONE, supra note 24 , at $* 129$ (emphasis added).

154. For example, the right to personal security could be violated by murder, as well as by unlawful execution. Id. at *133-34.

155. Id. at $* 123$.

156. Id. at $* 125$.

157. See id. at *122-144; 2 KENT, supra note 121, at *1-37.

158. See, e.g., 1 Blackstone, supra note 24 , at *129-30 (abortion); id. at *130-31 (mayhem, duress); id. at *133 (homicide); id. at $* 134$ (assault and battery, defamation); id. at $* 136-37$ (false imprisonment); 2 KENT, supra note 121, at *15 (criminal and tort law); id. at *16-17 (defamation); id. at 26 (false imprisonment). 


\section{Enforcement of Legal Rights}

As Blackstone observed, laws recognizing substantive rights would be a "dead letter" if there were no method for actually enforcing those rights. ${ }^{159}$ In its most basic meaning, protection referred to the means by which the law enforced the observance of rights.

These means of protection evolved over time. In principle, the sovereign's duty of protection had always extended to the prevention as well as the punishment of violence. Prior to the nineteenth century, however, the state's capacity to prevent violence was quite limited. Accordingly, the traditional notion of protection focused on the government's obligation to respond to injuries already suffered by affording a civil remedy and imposing criminal punishment. From a very early period, however, the common law provided some means of preventing violence before it occurred, including the process of requiring security of the peace and the responsibility of officers to keep the peace. During the nineteenth century, modern police forces were created to prevent crimes and thus afford more complete protection to person and property. Thus, by the time that the Fourteenth Amendment was adopted, the concept of protection had developed to include the state's obligation to take reasonable measures for the prevention of violence. This development is explored below.

1. Self-Defense. Classical writers viewed the right to protection against the background of the natural law of self-defense. In any situation where the government was unable to protect against threatened violence, the law allowed the individual to defend himself. ${ }^{160}$ In such situations, Blackstone observed, "the law of nature ... [has] made [the individual] his own protector."161 On the other hand, there was no right to use force in self-defense when a resort to the law was possible. ${ }^{162}$

2. Civil Protection. In the common law tradition, "the protection of the law" meant above all the ability to enforce one's rights in a civil action and thus obtain a remedy for their violation. ${ }^{163}$ As Chief Justice

159. 1 BLACKSTONE, supra note 24 , at *140-41; see also id. at *55-56.

160. See, e.g., 3 id. at *3; 4 id. at *180,*183-84; $2 \mathrm{KENT}$, supra note 121 , at *15.

161. 4 BLACKSTONE, supra note 24, at *30. Similarly, Kent wrote that, in such instances, "the law, with great propriety, and in strict justice, considers the individual to be under the protection of the law of nature." 2 KENT, supra note 121, at *15 (citation omitted). As Tucker explained, the individual "retains the right of repelling force by force; because that may be absolutely necessary for self-preservation, and the intervention of society in his behalf, may be too late to prevent an injury." 1 BLACKSTONE, supra note 24, at *145 (Tucker ed. note).

162. See 4 BLACKSTONE, supra note 24 , at *183-84.

163. See Calvin's Case, 7 Co. Rep. 1a, 13b, 77 Eng. Rep. 377, 393 (1608) ("If a man be attainted of felony or treason, he hath lost the King's legal protection, for he is thereby utterly disabled to sue 
Marshall declared in Marbury v. Madison:164 "The very essence of civil liberty certainly consists in the right of every individual to claim the protection of the laws, whenever he receives an injury. One of the first duties of government is to afford that protection."165

According to Coke and Blackstone, the right to a remedy was secured by chapter 29 of Magna Carta, which provided that justice should not be denied. 166 Under this provision, Coke wrote, "[e]very subject ... for injury done to him [in goods, lands, or person], by any other subject . . . may take his remedy by the course of law, and have justice, and right for the injury done to him, freely without sale, fully without any denial, and speedily without delay."167 Coke's paraphrase of Magna Carta was incorporated in some form in most of the antebellum state constitutions. ${ }^{168}$

In one sense, the right to civil protection might be viewed as merely procedural, consisting in the right to bring a lawsuit. As Coke's statement indicates, however, the concept of civil protection had substantive content as well. In the classical legal tradition, it was axiomatic that "where there is a legal right there is also a legal remedy, . . . whenever that right is invaded." 169 Indeed, a central purpose of Blackstone's Commentaries was to show that the common law accorded with the law of nature in recognizing fundamental rights, and gave a remedy for all invasions of those rights. ${ }^{170}$ Thus, the right to civil protection was substantive, not merely procedural or formal: It sought to ensure that individuals were actually able to obtain remedies for the invasion of their rights by others.

any action real or personal."); 1 COKE, supra note 20, at *130a; 1 BLACKSTONE, supra note 24, at *56 ("This is what we mean properly, when we speak of the protection of the law.").

164. 5 U.S. (1 Cranch) 137 (1803).

165. Id. at 163.

166. See Magna Carta ch. 29 (1225) (Eng.); 1 Blackstone, supra note 24, at *141; 2 CoKE, supra note 20 , at $* 55$.

167. 2 CoKe, supra note 20 , at *55.

168. See, e.g., ALA. CONST. of 1819 , art. I, $\S 14$, reprinted in 1 STATE Constitutions, supra note 13 , at 32; CONN. CONST. of 1818 , art. $1, \S 12$, reprinted in 2 STATE CONSTITUTIONS, supra note 13 , at 145; DEL. CONST. of 1831, art. I, $\$ 9$, reprinted in 2 STATE CONSTITUTIONS, supra note 13, at 217-18; FLA. CONST. of 1838, art. $\backslash, \S 9$, reprinted in 2 STATE CoNSTITUTIONS, supra note 13, at 317.

169. 3 BLACKSTONE, supra note 24 , at $* 23$; see also id. at $* 86$, 422 ("[E]very possible injury that can be offered to a man's person or property is certain of meeting with redress" in some court.).

170. See id. at *1-2. Of course, Blackstone recognized that in some respects the common law was defective. See, e.g., 1 id. at *143 (right to petition when law is "too defective" to give remedy for injury); id. at *171-72 \& n.n (laws not as perfect as he presents them as being). For present purposes, the important point is that classical legal theory held that it was necessary for the law to provide remedies for all injuries to fulfill its function of protection. 
3. Criminal Protection. In addition to civil protection, the individual had a right to protection under the criminal law. As Kent expressed it, "the personal security of every citizen is protected from lawless violence by the arm of government and the terrors of the penal code." 171

According to classical legal theory, criminal law has its foundation in the law of nature. ${ }^{172}$ That law forbids violations of the natural rights of others, such as murder or theft. ${ }^{173}$ In a state of nature, everyone has the power to punish offenses against the law of nature. ${ }^{174}$ When they enter into the social contract, individuals give up this power of criminal punishment to the society, to be exercised for the protection of its members. ${ }^{175}$

As we have seen, the state's responsibility for providing this protection was shared among the three branches of government. ${ }^{176}$ The legislature had an obligation to enact criminal laws for the protection of life, liberty, and property, while the executive and the courts had a duty to enforce those laws to protect the community and its members against violence. This enforcement function was known in traditional English law as the conservation of the peace. ${ }^{177}$ As we shall see, it included the prevention of violence ${ }^{178}$ as well as the arrest, prosecution, and punishment of offenders. ${ }^{179}$

The right to criminal protection was even more fundamental than the right to a civil remedy for injuries. Under the traditional common law, an individual who fled from justice was declared an outlaw, that is, one who was "out of the protection of the law."180 Outlaws, and capital felons, ${ }^{181}$ forfeited the protection of the law in a civil sense: They were

171. 2 KENT, supra note 121 , at *15.

172. See 1 BLACKSTONE, supra note 24 , at *41-43, *54.

173. Id. at * $42-43, * 54$.

174. See 4 id. at *7-8; Locke, supra note 25 , $\$ \S 7-8$.

175. See 4 Blackstone, supra note 24 , at *8; LockE, supra note 25 , $\S \S 128-130$. As Tucker explained:

When a man quits the state of nature, and enters into a state of society, he resigns into the hands of society the right of punishing an offender, for an injury already done him, the society by the terms of the social compact, having engaged to punish every such offender for him.

4 Brackstone, supra note 24 , at *145 (Tucker ed. note).

176. See supra text accompanying notes 60-67.

177. See 1 BLACKSTONE, supra note 24 , at *349-51, *353-54.

178. See infra text accompanying notes 185-241.

179. See 1 BlaCkSTONE, supra note 24 , at $* 266, * 268, * 270$.

180. Id. at *284.

181. The protection of the law was forfeited upon conviction of a capital felony, 4 id. at $* 380$, as well as of the crime known as praemunire, id. at $* 117-18$. 
disabled from suing for any private injuries they suffered. ${ }^{182}$ Nonetheless, they continued to be under the protection of the law in the criminal context. ${ }^{183}$ Thus, to kill an outlaw or a felon without lawful justification constituted murder. ${ }^{184}$

4. Prevention of Injury. As I have noted, the government's duty of criminal protection included the prevention as well as the punishment of violence. ${ }^{185}$ The traditional common law provided two important means of prevention: the process of requiring security of the peace, and the authority of officers to keep the peace.

a. Security of the peace. "[E]very person," Kent observed, "is . . . entitled to the preventive arm of the magistrate, as a further protection from threatened or impending danger."186 By "the preventive arm of the magistrate," Kent meant the common law process of requiring security for the peace. ${ }^{187}$ Under this procedure, any person under the sovereign's protection who feared a violent attack by another had a right to apply to a justice of the peace to have his adversary bound to keep the peace. ${ }^{188}$ The justice was bound to grant the application if the demandant showed just cause to fear death or bodily harm. ${ }^{189}$ The justice also

182. See 3 id. at $* 284 ; 4$ id. at $* 117$.

183. See 4 id. at $* 117-18$; id. at $* 319-20$. Under early law, an outlaw forfeited the protection of the law in all respects, and might lawfully be killed. See $i d$. at $* 320$.

184. See id. at *178, *319-20. As defined by Blackstone, the crime of murder consisted of killing, with malice aforethought, any person "under the king's peace and protection." Id. at *195, *197-98.

185. See supra text accompanying notes $178-79$; see also 4 BLACKSTONE, supra note 24 , at *2, *251. Indeed, Blackstone, following Beccaria, maintained that "preventive justice is ... preferable in all respects to punishing justice," which although necessary is often harsh. Id. at *251 (citing BECCARIA, CRIMES AND PUNISHMENTS ch. 41 (Albany, W.C. Little 1872) (1764)).

186. 2 KENT, supra note 121 , at $* 15$.

187. The law governing this process is described in 4 BLACKSTONE, supra note 24 , at $* 251-57$, and in 5 Nathan Dane, A General Abridgment and Digest of American law 301-05 (1824).

188. 4 BlACKSTONE, supra note 24 , at $* 253$, $* 255$.

189. Id. at *255; 5 DANE, supra note 187 , at 301 . As Blackstone observed, wives had a right to demand security of the peace against their husbands, and vice versa. 4 BLACKSTONE, supra note 24, at $* 254$; see also 1 id. at $* 442$. In this and other respects, the process of the peace resembled the modern protective order in domestic violence cases.

In Balistreri v. Pacifica Police Dep't, 855 F.2d 1421 (9th Cir. 1988), the Court of Appeals for the Ninth Circuit held that the police department violated the Due Process Clause by refusing to enforce a protective order that the plaintiff had obtained against her estranged husband. The Supreme Court implicitly disapproved this holding in DeShaney v. Winnebago County Social Servs. Dep't, 489 U.S. 189, 197 n.4 (1989). As this history shows, however, the protective order is closely related to a procedure that was considered to be an integral part of the right to protection in the classical legal tradition. 
had broad authority, on his own motion, to require security of the peace from persons who appeared likely to break it. 190

A party who was bound to keep the peace was required to find one or more sureties, who together with the party entered into a bond or recognizance for a large sum to be forfeited to the state in the event that he committed a breach of the peace against the demandant. ${ }^{191}$ A party who did not find adequate sureties could be committed until he did. ${ }^{192}$

As Kent's statement indicates, the right to security of the peace was viewed as an important aspect of the general right to protection by the government. Conversely, the availability of such legal protection imposed a limitation on the individual's natural right to self-defense, "for, instead of attacking one another for injuries past or impending, men need only have recourse to the proper tribunals of justice." 193 Accordingly, the right to self-defense was limited to cases where the threatened harm was "immediate" and there was no time to obtain "the assistance of the law."194

b. Protection by peace officers. In addition to security for the peace, traditional law provided another important means of preventing violence: the responsibility of officers to maintain the peace. As we have seen, the executive had a duty to enforce the criminal laws to protect the community and its members from violence. ${ }^{195}$ This function was performed by officers known as "conservators of the peace," a category that included justices of the peace, sheriffs, and constables. ${ }^{196}$ As their name indicates, it was the general duty of these officers to keep the peace. ${ }^{197}$ That duty included preventing violence as well as apprehending offenders. ${ }^{198}$ Where necessary, the sheriff and justices had authority to

190. 4 BlACKSTONE, supra note 24 , at $* 254-55$.

191. Id. at $* 252-53$.

192. Id. at $* 255$.

193. Id. at * 184 (emphasis added).

194. Id.

195. See supra text accompanying note 64.

196. See 1 BlaCKSTONE, supra note 24 , at $* 349-50$.

197. See id. at *350 (authority of conservators to keep the peace); id. at *354 (duty of justices of the peace); id. at *356 (duty of constable).

198. See id. at *343 (stating that the sheriff has the power to "apprehend, and commit to prison, all persons who break the peace, or attempt to break it") (emphasis added); id. at *353-54 (observing that, at common law, the power and duty of conservators of the peace included "suppressing riots and affrays, ... taking securities for the peace, and ... apprehending and committing felons and other ... criminals"); 4 id. at "145 (noting duty of constable to keep the peace by suppressing affray).

For a late-nineteenth-century recognition of the duty of peace officers to protect citizens against violent assault, see In re Neagle, 135 U.S. 1, 69 (1890). 
command the power of the county (posse comitatus) to assist them in performing their duties. ${ }^{199}$

An officer who failed to keep the peace was subject to criminal prosecution for neglect of duty. ${ }^{200}$ At common law, however, an individual who sustained injury because of an officer's failure to prevent violence apparently had no remedy against either the state, the local government, or the officer. Although the state, through its officers, had failed to afford protection, it was exempt from liability under the doctrine of sovereign immunity. ${ }^{201}$ One alternative was to bring suit against the local government. In statutes of incorporation, states delegated to municipal governments the responsibility to protect persons and property within their jurisdiction. During the mid-nineteenth century, suits were sometimes brought against local governments for failing to protect against violence. As we shall see, such claims were consistent with a long tradition of communal liability in England, and were specifically authorized by statute in several American states. ${ }^{202}$ In the absence of statute, however, the courts rejected such claims on the ground that local governments were entitled to immunity when exercising "governmental functions" delegated by the state. ${ }^{203}$

A final alternative was to bring suit against the officer. Legal writers sometimes asserted in broad terms that public officers were liable for injuries caused by neglect of duty. ${ }^{204}$ On the other hand, the common law

199. See 1 Blackstone, supra note 24 , at $* 343-44$; 4 id. at $* 122$.

200. See 4 id. at *140 (describing "the negligence of public officers," which was a misdemeanor at common law). In addition, a number of English statutes imposed fines on officers who failed to perform specific duties to keep the peace. See, e.g., id. at *293-94 (describing statute making constable liable to fine for refusing or neglecting to make hue and cry).

201. On the doctrine of sovereign immunity, see 1 id. at $* 242-48 ; 3$ id. at $* 254-55$. The origins and development of the doctrine are briefly traced in PETER H. SCHUCK, SUING GoverNMENT: CTIIZEN REMEDIES FOR OfFICIAL WRONGS 30-41 (1983). The classic work on the subject is Edwin M. Borchard's multipart article, Government Liability in Tort, 34 YALE L.J. 1, 129, 229 (1924-1925); 36 YALE L.J. 1, 757, 1039 (1926-1927); 28 Colum. L. REv. 577, 734 (1928).

202. See infra text accompanying notes 218-25.

203. See, e.g., Prather v. City of Lexington, $52 \mathrm{Ky}$. (13 B. Mon.) 559 (1852); Western College of Homeopathic Medicine v. City of Cleveland, 12 Ohio St. 375 (1861). In Western College, for example, it was alleged that city officials had negligently failed to protect the college's building from destruction by a riot. Although acknowledging that "[i]t is the duty of the state government to secure to the citizens of the state the peaceful enjoyment of their property and its protection from wrongful and violent acts," the Ohio Supreme Court denied recovery on the ground that, in performing this function, the municipal government "represents the state," and thus should share its immunity. Id. at 377 .

204. Dane, for example, declared that "[i]n every case in which an officer is intrusted by common law, or by statute, to perform a service, and neglects it, this action [for negligence] lies against him by the party injured." 3 DANE, supra note 187 , at 33 . Blackstone stated the principle in similarly broad terms. See 3 BLACKSTONE, supra note 24 , at $* 165$. 
accorded immunity to officials exercising "judicial" functions. ${ }^{205}$ Before the mid-nineteenth century, the issue of whether officials were subject to civil liability at common law for failing to protect against violence had never been resolved authoritatively.

The issue came before the Supreme Court during the 1850s in South v. Maryland ex rel. Pottle. ${ }^{206}$ Jonathan Pottle, the real plaintiff, alleged that in June 1850 he was going about his lawful business in Washington County, Maryland, when he was set upon by certain persons who threatened his life and personal safety, and detained him until he should pay them a large sum of money. Pottle asserted that he then applied to the sheriff of Washington County, Daniel South, "to protect and defend him ... from [such] unlawful conduct and threatened violence ... , and to preserve and keep the peace of the State of Maryland," but that South, although he had the necessary power and authority, failed to do so.207 Pottle claimed that as a result he was forced to pay his captors $\$ 2500$ for his release. ${ }^{208}$

Pottle brought a diversity action in federal court against South and his sureties for damages caused by the sheriff's alleged failure to protect him. A jury trial resulted in a substantial judgment for the plaintiff. The defendants then brought a writ of error in the Supreme Court. After the case was initially argued, the Court ordered reargument, directing the parties to focus on the question of whether a conservator of the peace was subject to civil liability in such circumstances. ${ }^{209}$

In 1856, the Supreme Court issued a decision reversing the judgment. Writing for the Court, Justice Grier recognized that the sheriff had a duty to preserve the peace, but ruled that there was no civil liability at common law for a breach of this duty. The decision was based on a distinction between "ministerial" and "public" duties.210 An officer acted in a ministerial capacity when he was "bound to render certain services to individuals, for a compensation in fees or salary."211 A prime example was the execution of process on behalf of a party in a civil

205. See generally J. Randolph Block, Stump v. Sparkman and the History of Judicial Immunity, 1980 DUKE L.J. 879.

206. 59 U.S. (18 How.) 396 (1856).

207. Id. at 399.

208. Id. at 398-99. The record of the case in the Supreme Court sheds light on these allegations. Pottle, together with his partners, had invested in a mill in Washington County. After the mill owner defaulted on the debt, Pottle and his partners recovered a judgment against him. While accompanying a deputy sheriff to an execution on the mill, Pottle was detained by the mill's workers who demanded that he pay them wages that they claimed were due them. See Record at 9.

209. South, 59 U.S. (18 How.) at 396.

210. See id. at 402-03.

211. Id. at 402 . 
case. ${ }^{212}$ When performing such functions, the officer was "liable for acts of misfeasance or non-feasance to the party who is injured by them."213

Under traditional common law doctrine, an officer was immune from civil liability where he acted in a judicial capacity. Although " $t]$ he powers and duties of conservator of the peace exercised by the sheriff are not strictly judicial," Justice Grier reasoned, "he may be said to act as the chief magistrate of his county, wielding the executive power for the preservation of the public peace."214 Expanding the category of "judicial" duties to include other "public" duties-such as conservation of the peace-the Court declared as a general principle that, for the breach of a public duty, an officer is responsible to the public only, and thus is subject to criminal, but not civil, liability. ${ }^{215}$

It is important to recognize that South did not hold that a conservator of the peace had no duty to protect citizens against violence. On the contrary, the opinion indicates that he did have such a duty, and that he was subject to criminal punishment at common law if he neglected to perform it. ${ }^{216}$ More broadly, South might be interpreted as implying that protection against violence was not a duty that the state owed to individuals as such, but only to the public at large. Such an interpretation, however, confuses the duty of the officer with that of the state. Under the South doctrine, an officer is responsible only to the public, that is, to the state, for failure to perform his public duties. Nothing in South, however, is inconsistent with the principle that the state owes a duty of protection to each of its members. But an individual has no legal remedy against the state because of the doctrine of sovereign immunity. In effect, South extends the state's immunity to public officers when they act as representatives of the state in performing such functions as conserving the peace. ${ }^{217}$ Thus, the effect of the South rule, in combination with the doctrines of state and local government immunity, was to deny any remedy at common law for the government's failure to prevent criminal violence.

c. Communal liability. During the mid-nineteenth century, a number of states responded to the lack of an effective remedy by enacting statutes. These statutes typically imposed liability on cities and counties for property damage, and sometimes for personal injuries, caused by

212. Id.

213. Id. at $402-03$.

214. Id. at 403.

215. See id. at 402 .

216. See id. at 403.

217. See id. at 402 ("As conservator of the peace in his county or bailiwick, [the sheriff] is the representative of the king, or sovereign power of the State for that purpose."). 
riots within their jurisdictions. Some of these statutes also made officers civilly liable when they failed to use their authority to prevent such harm.

In enacting such laws, American states were following a much older English tradition of communal liability for certain kinds of violence. Under legislation going back to the Statute of Winchester, ${ }^{218}$ the local community known as the hundred was required to pursue felons, and to compensate victims of robberies within its jurisdiction in cases where the community failed to apprehend the thief. ${ }^{219}$ Similarly, the Riot Act of 1714 made the hundred liable for property damage caused by riots. 220

By 1868 , when the Fourteenth Amendment was ratified, at least nine states had enacted riot laws similar to the English acts. ${ }^{221}$ Pennsylvania's law, adopted in 1841, provided a model for later statutes. ${ }^{222}$ The law authorized individuals to bring suit against the county to recover damages for the destruction of any real or personal property by any mob or riot within its jurisdiction. As a condition of recovery, the owner was required, if there was sufficient time, to notify a conservator of the peace of the attack on the property. Upon receipt of such notice, the officer had a "duty ... to take all legal means to protect the property so attacked."223 If the officer failed to perform this duty, he became civilly liable to the owner for damages to the property. If the plaintiff recovered against the county, the county was given an action over against the rioters, or against any officer who had failed to perform his duty to suppress the riot.

As the Pennsylvania statute makes clear, these state laws reaffirmed the community's duty of protection and made it the basis of a legal action. As the Pennsylvania Supreme Court explained, these acts recognized that "tax-payers have a right to be indemnified for losses occasioned by lawless outrage, whenever the public are unable or unwilling to protect property."224 Similarly, in upholding the constitutionality

218. 13 Edw., stat. 2, ch. 1-3 (1285) (Eng.).

219. See 4 Blackstone, supra note 24 , at *293-94.

220. Riot Act, 1714, 1 Geo., ch. $5, \S 6$ (Eng.).

221. See 1868 Cal. Stat. ch. 344; 1855 La. Sess. Laws no. 51; 1835 Md. Laws ch. 137; 1839 Mass. Acts 54; 1854 N.H. Laws ch. 1519; 1864 N.J. Laws ch. 150; 1855 N.Y. Gen. Mun. Laws ch. 428; $1841 \mathrm{~Pa}$. Laws no. 144, §§ 7-11; 1863 Wis. Laws ch. 211.

222. See $1841 \mathrm{~Pa}$. Laws no. $144, \S \S 7-11$. The provisions summarized in this paragraph are found in section 8 of the act.

As originally enacted, the Pennsylvania statute applied only to the county of Philadelphia; it was subsequently extended to certain surrounding counties. See $1849 \mathrm{~Pa}$. Laws 184, § 1; $1863 \mathrm{~Pa}$. Laws 499, § 1 . The riot statutes of other states applied statewide. See supra note 221.

223. $1841 \mathrm{~Pa}$. Laws no. $144, \S 8$.

224. In re Pennsylvania Hall, $5 \mathrm{~Pa} .204,209$ (1847) (applying a predecessor of the 1841 act). The case involved the burning of a hall used for abolitionist meetings. 
of the New York law, the Court of Appeals of New York explained that the statute was intended to compensate:

those who may be so unfortunate, as without their own fault to be injured in their property by acts of lawless violence of a particular kind which it is the general duty of the government to prevent; and further and principally ... to make it the interest of every person liable to contribute to the public expenses to discourage lawlessness and violence .... These ends are plainly within the purposes of civil government, and indeed it is to attain them that governments are instituted. 225

Thus, the state riot acts strongly confirm that, in nineteenth-century legal thought, the government's duty of protection was understood to include the prevention as well as the punishment of violence. Moreover, they show that some states provided a legal remedy in certain cases for the government's failure to afford such protection.

d. The creation of modern police forces. Law enforcement in England and America traditionally relied on the efforts of a few officers, with the assistance of citizens where necessary. By the nineteenth century, this reliance on a "haphazard collection of constables and night watchmen"226 seemed increasingly inadequate, especially in urban areas. In response to growing concerns about riots and crime, major cities began to create modern police forces-relatively organized units whose purpose was to prevent crime. ${ }^{227}$ The legislative debates over the creation of such forces in England and America reflect the view that an effcient police force might be essential for the protection of person and property.

225. Darlington v. City of New York, 31 N.Y. 164, 187 (1865). For other contemporary statements that the riot statutes were based on the duty of protection, see Ely v. Supervisors of Niagara County, 36 N.Y. 297, 300 (1867); Luke v. City of Brooklyn, 43 Barb. 54, 56-57, 58 (N.Y. App. Div. 1864); Curtis v. County of Allegheny, 1 Phil. Rep. 237, 239-40 (Pa. Dist. Ct. 1851).

This view was echoed by the Supreme Court half a century later in City of Chicago v. Sturges, 222 U.S. 313 (1911). In Sturges, the city challenged the Illinois riot act under the Due Process Clause of the Fourteenth Amendment. Rejecting this claim, the Court declared:

[T] he obligation of the government to protect life, liberty and property against the conduct of the indifferent, the careless and the evil-minded may be regarded as lying at the very foundation of the social compact. ... The law in question ... rests upon the duty of the State to protect its citizens in the enjoyment and possession of their acquisitions, and is but a recognition of the obligation of the State to preserve social order and the property of the citizen against the violence of a riot or a mob.

Id. at 322 .

226. Lawrence M. Friedman, A History of American law 287 (2d ed. 1985).

227. On the creation of modern police forces, see id.; KERMIT L. HALL, THE MAGIC MIRROR: LAW in American History 176-78 (1989); SAMUel. Walker, Popular Justice (1980). For leading studies of individual cities, see Roger LANE, Policing THE CrTY: Boston, 1822-1885 (1967); Wilbur Miller, CoPs aNd Bobbies: Police Authority IN NEW YoRK AND LONDON, 1830-1870 (1977); James F. Richardson, The New York Police (1970); Allen Steinberg, The Transformation of Criminal Justice: Philadelphia, 1800-1880 (1989). 
The first modern police force was established in London by the Metropolitan Police Act of 1829.228 In a speech introducing the Act in Parliament, the home secretary, Sir Robert Peel, argued that the existing nightwatch system was wholly inadequate to combat sharply increasing rates of crime. ${ }^{229}$ Legislative action was necessary "not only to prevent such ... outrage against the laws, but to provide more secure means of protecting the person and the property of the subject."230 Responding to the objection that a more powerful police force would threaten liberty, Peel observed that liberty included the sense of security that one's life and property would not be assaulted. ${ }^{231}$ It was "the duty of the legislature," he concluded, to "afford to the inhabitants of the metropolis ... the full and complete protection of the law, and to take prompt and decisive measures to check the increase of crime."232

During the following decades, several American cities established police forces based on the London model. Philadelphia experimented with such a system as early as 1833; Boston established a police force in 1838; and New York followed in 1845.233

Congressional debates in 1858 over a proposal to reform the District of Columbia police make clear that Americans shared the view that protection might require a modern police force. The legislation's rationale was articulated by its Democratic supporters. It was "the object of government," observed one member, "to protect the people in their personal liberty, their personal security, and their rights of private property."234 The "conservation of life and of property" was the function of a police. 235 Under existing legislation, it was the duty of the city authorities to maintain order, but they were either unwilling or unable to do so.236 As a result, Washington was overwhelmed by an "epidemic of crime," in which murder and robbery were a "daily occurrence."237 "[W]e all know," declared Senator Stephen A. Douglas, "that life is not safe in this city at present; men are cut down and shot at the doors of citizens, who

228. $10 \mathrm{Geo} .4$, ch. 44 (1829) (Eng.).

229. See 21 PARL. Deb. (2d ser.) $867-84$ (1829).

230. Id. at 875 .

231. See id. at 882. On the identification of liberty with security in this context, see MILLER, supra note 227, at 108-09.

232. 21 PARL. Deb. (2d ser.) at 882 (emphasis added). For a similar speech supporting the Act in the House of Lords, see id. at 1750-52 (speech of the Duke of Wellington).

233. See FrIEDMAN, supra note 226, at 287; HALL, supra note 227, at 176.

234. CONG. GlOBE, 35th Cong., 1st Sess. 1592 (1858) (remarks of Rep. Hughes).

235. Id. at 1594 (remarks of Rep. Cochrane) ("[T]he office of a police is concededly that of the conservation of life and of property.").

236. RePort of the SenATE COMM. ON THE District of Columbia, printed in Cong. GLOBE, 35th Cong., 1st Sess. 1460 (1858).

237. Id.; CONG. GLOBE, 35th Cong., 1st Sess. 1586 (remarks of Rep. Maynard). 
dare not open their doors to rescue the wounded for fear of being killed themselves."238 Democrats argued that it was the duty of Congress, as the exclusive legislative authority over the District, to afford protection against such violence. ${ }^{239}$ Therefore, they concluded, Congress had an obligation "to provide for an adequate and efficient police in this city, so as to preserve the peace and secure the lives and property of individuals." 240

5. Conclusion. The right of protection was thus a well established concept in antebellum legal thought. In addition to the right of self-defense, it included civil remedies and criminal protection, as well as the process of requiring security for the peace. By the middle of the nineteenth century, the concept of protection had developed to include the state's responsibility to take reasonable measures to prevent violence, such as the creation of a police force where necessary for the protection of life and property. As the Supreme Court explained toward the end of the century:

It has in modern times become apparent that the physical health of the community is more efficiently promoted by ... preventive means, than by the skill which is applied to the cure of the disease after it has become fully developed. So also the law, which is intended to prevent crime ... by regulations, police organization, and otherwise, which are adapted for the protection of the lives and property of citizens, .... is more efficient than punishment of crimes after they have been committed. ${ }^{241}$

\section{The Fourteenth AMENDMENT}

Although the right to protection was a fundamental principle of general constitutional and legal theory, it had limited recognition in the original Constitution. Instead, in most respects, the Constitution left the protection of the rights of individuals under the control of the states. ${ }^{242}$ Moreover, slavery meant that most blacks were denied all protection of their rights, a principle asserted by the Supreme Court in the Dred Scott case, ${ }^{243}$ which declared that blacks had no rights that whites were bound to respect. ${ }^{244}$

238. CONG. GLOBE, 35th Cong., 1st Sess. 1461 (1858).

239. See id. at 1465 (remarks of Sen. Crittenden); id. at 1468 (remarks of Sen. Green); id. at 1572 (remarks of Rep. Singleton); id. at 1612 (remarks of Rep. Scales).

240. Id. at 1465 (remarks of Sen. Crittenden).

241. In re Neagle, 135 U.S. 1, 59 (1890).

242. See supra text accompanying notes 94-98.

243. Dred Scott v. Sandford, 60 U.S. (19 How.) 393 (1857).

244. Id. at 407. 
A central purpose of the Fourteenth Amendment and Reconstruction legislation was to establish the right to protection as a part of the federal Constitution and laws, and thus to require the states to protect the fundamental rights of all persons, black as well as white. In establishing a federal right to protection, the Fourteenth Amendment was not creating a new right, but rather incorporating into the Constitution the concept of protection as understood in the classical tradition. The debates in the Thirty-Ninth Congress over the Fourteenth Amendment and the Civil Rights Act of $1866^{245}$ confirm that the constitutional right to protection was understood to include protection against private violence.

\section{A. The Need for a Federal Guarantee of the Right to Protection}

In accordance with the antebellum tradition, members of the ThirtyNinth Congress regarded the right to protection as axiomatic. It was a "self-evident" principle, declared Representative Samuel Shellabarger of Ohio, "that protection by his Government is the right of every citizen."246 In support of this right, Republicans invoked both the traditional doctrine of allegiance and protection, and the theory of natural rights.

There was general agreement that the citizen was entitled to protection in return for obedience. "Protection and allegiance are reciprocal," asserted Senator Alvin Stewart of Nevada. "It is the duty of the Government to protect; of the subject to obey."247 "[T]hese are the essential elements of citizenship," agreed Senator Justin Morrill of Vermont, "allegiance on one side and protection on the other."248 Many other Republicans invoked the same principle. ${ }^{249}$

Republicans also appealed to the natural rights tradition as a basis for the duty of protection. ${ }^{250}$ Relying on the Declaration of Independence, Blackstone, and Kent, they contended that the rights to

245. Ch. 31, 14 Stat. 27 (codified at 42 U.S.C. $\S \S 1981-1982$ (1988)).

246. Cong. Globe, 39th Cong., 1st Sess. 1293 (1866).

247. Id. at 2799.

248. Id. at 570 .

249. See, e.g., id. at 1152 (remarks of Rep. Thayer); id. at 1263 (remarks of Rep. Broomall); id. at 1293-94 (remarks of Rep. Shellabarger); id. at 1757 (remarks of Sen. Trumbull); id. at 1832 (remarks of Rep. Lawrence); id. at 2918 (remarks of Sen. Willey).

250. Jacobus tenBroek and Howard Jay Graham explored the influence of natural rights thought in their classic studies of the Fourteenth Amendment. See Howard J. GraHAM, EverymaN's CONSTITUTION (1968); TENBROEK, supra note 10. In recent years, a number of other scholars have emphasized the natural rights background to the Fourteenth Amendment. See, e.g., CURTIS, supra note 127; FARBER \& SHERRY, supra note 44, at 253-319; Robert J. Kaczorowski, Revolutionary Constitutionalism in the Era of the Civil War and Reconstruction, 61 N.Y.U. L. REV. 863 (1986). 
life, liberty, and property were "natural" and "inalienable."251 The protection of "these great fundamental rights," declared Representative James Wilson of Iowa, is "the first and most important office of government."252

Following the classical view, the Framers also identified liberty with protection. ${ }^{253}$ Thus, in the course of an important speech on the Civil Rights Act, Senator Lyman Trumbull of Illinois defined constitutional liberty in terms of Blackstone's conception of civil liberty, in which the individual's natural liberty was subject to limitation in return for "the protection which civil government gives him."254 Freedom "does mean protection," agreed Senator James A. McDougall, Democrat of California. "Under all Governments that are free, freedom is perfect protection in life, liberty, and the enjoyment and pursuit of happiness."255

As McDougall's remarks indicate, the right to protection was recognized even by the Democrats and conservative Republicans who opposed the Civil Rights Act and the Fourteenth Amendment.256 Conservatives insisted, however, that under the federal system "all the arrangements of life with regard to the protection of property and person" were exclusively committed to the states. ${ }^{257}$ There was no reason, they argued, "to assume that a State will not do its duty to its citizens in these particulars."258

Most Republicans, however, believed that the states had failed to fulfill this duty, in the past as well as the present. No state, declared Representative John A. Bingham of Ohio, ever had a "right to deny protection to any free citizen of the United States within their limits in the

251. See, e.g., CoNG. Globe, 39th Cong., 1st Sess. 474-75, 1757 (1866) (remarks of Sen. Trumbull); id. at 1088 (remarks of Rep. Woodbridge); id. at 1117-18 (remarks of Rep. Wilson); id. at 1152 (remarks of Rep. Thayer); id. at 1159 (remarks of Rep. Windom); id. at 1832-33 (remarks of Rep. Lawrence); id. at 2798 (remarks of Sen. Stewart).

252. Id. at 1118.

253. See supra Part I(C) (discussing classical conception of liberty).

254. CoNG. GLOBE, 39th Cong., 1st Sess. 474 (1866).

255. Id. at 393. In this speech, McDougall opposed the Freedmen's Bureau Bill on the ground that blacks should merely receive the ordinary protection of the law, rather than be treated as special wards of the federal government. See id.

256. See, e.g., id. at 476 (remarks of Sen. McDougall) (stating that blacks "should be conceded" the rights to "protection [in] the enjoyment of life and liberty and the pursuit of happiness and the protection of the courts"); id. at 989 (remarks of Sen. Cowan) ("I hold that it is the duty of every Government to protect its subjects . ..."); id. at 2919 (remarks of Sen. Davis) (acknowledging the "universal maxim" that "it is the duty of the Government to protect the citizen"). That this view was shared by Democrats as well as Republicans is made clear by the 1858 debates over police reform in the District of Columbia. See supra text accompanying notes 234-40.

257. ConG. GlobE, 39th Cong., 1st Sess. 1123 (1866) (remarks of Rep. Rogers); see also id. at 1270 (remarks of Rep. Kerr).

258. Id. at 1270 (remarks of Rep. Kerr). 
rights of life, liberty, and property."259 Yet, as Representative John M. Broomall of Pennsylvania observed, during the intense national controversy over slavery between 1830 and 1860, "everybody knows that the rights and immunities of citizens were habitually and systematically denied in [the southern] States to the citizens of other States."260 Since the war began, stressed Bingham, the Confederate states had flagrantly violated the rights of citizens who had remained loyal to the Union.261

Above all, the southern states had denied protection to blacks held as slaves. Under the laws of the slave states, Senator Jacob M. Howard of Michigan explained, a slave "was nothing but a chattel, subject to the will of his owner, and unprotected in his rights by the law of the State where he happened to live."262 The status of slavery, Bingham agreed, meant that blacks had been refused "protection in life [and] property."263

The Emancipation Proclamation and the Thirteenth Amendment had abolished slavery, and had thereby made the slaves freemen. In late 1865 , southern legislatures responded by enacting "black codes" that restricted the rights of blacks in a wide range of ways, including their freedom of movement and their rights to dispose of their own labor, to hold property, and to testify in court.264 In the view of many Republicans, these laws were incompatible with the status of a freeman, and constituted an effort by southern states to reduce blacks to slavery in all but name.

During the latter half of 1865 , the nation also began to receive reports from the South of widespread violence against blacks as well as white Unionists and Northerners. ${ }^{265}$ These reports came from northern journalists, Freedmen's Bureau officials, travelers in the South, and white and black Southerners themselves. ${ }^{266}$ Among the most influential accounts was that of Carl Schurz, who toured the region at the request of President Johnson to report on the prospects for Reconstruction. ${ }^{267}$

Most Southerners, Schurz found, acknowledged the fact of military defeat, but had not accepted the "social revolution" involved in the abolition of slavery and its replacement by free labor. ${ }^{268}$ The efforts of planters to hold blacks in continued subjection were responsible for a "large

259. Id. at 1090 .

260. Id. at 1263; see also id. at 1066 (remarks of Rep. Price).

261. See id. at 1090-91, 1093-94.

262. Id. at 504 .

263. Id. at 1090.

264. See ERIC FoNER, RECONSTRUCTION, 1863-1877, at 198-202 (1988).

265. Id. at 224-25.

266. Id.

267. See S. Exec. Doc. No. 2, 39th Cong., 1st Sess. 3 (1865).

268. See id. at $45,38,45-46$. 
proportion of the many acts of violence" perpetrated against them. ${ }^{269}$ Moreover, "[n]ot only the former slaveholders, but the non-slaveholding whites ... a are possessed by a singularly bitter and vindictive feeling against the colored race," which led to a "very great" number of murders, maimings, and assaults. 270 Local officials and communities were either "not willing or not able to enforce peace and order."271 As one Freedmen's Bureau agent had reported: "As to protection from the civil authorities, there is no such thing," other than as a direct result of the military presence of the Bureau. ${ }^{272}$

Although violence was most frequently directed against blacks, Schurz reported that outrages had also been committed against white Unionists and federal soldiers. 273 Indeed, in many parts of the South, general lawlessness prevailed, with the local authorities unable to maintain order and security. ${ }^{274}$ In short, the South was "drift[ing] into anarchy."275 In conclusion, Schurz strongly urged that the federal government retain military control over the South until the social revolution was completed, a system of free labor was firmly established, the

269. Id. at 17.

270. Id. at 20.

271. Id.

272. Id. at 19. The agent, Captain J.H. Weber, wrote to the assistant commissioner of the Bureau as follows:

In the immediate vicinity of our military posts, and in locations that can readily be reached by the officers of this bureau, the citizens are wary of abusing the blacks; they are so because this bureau has arrested and punished people committing such offenses .... . But in remote localities ... the blacks are as badly treated as ever; colored people often report themselves to the sub-commissioners with bruised heads and lacerated backs, and ask for redress, protection, to be permitted to live at their former homes, and some assurance that they will not be treated in a like manner again if they return. But nothing can be done if their homes happen to be twenty or thirty miles from any office that will protect them....

...

As to protection from the civil authorities, there is no such thing outside of this city. There is not a justice of the peace or any other civil officer in the district, eight (8) counties, of which I have charge, that will listen to a complaint from a negro; and in the city, since the adjudication of these cases has been turned over to the mayor, the abuse of and impositions upon negroes are increasing very visibly, for the reason that very little, if any, attention is paid to any complaint of a negro against a white person.

Id. at 77-78.

273. Id. at 7-9.

274. Id. at 14. Schurz wrote:

In many districts robbing and plundering was going on with perfect impunity; the roads were infested by bands of highwaymen; numerous assaults occurred, and several stage lines were considered unsafe. The [accompanying statements of several military officers] give a terrible picture of the state of things in the localities they refer to. It is stated that civil officers are either unwilling or unable to enforce the laws; that one man does not dare to testify against another for fear of being murdered, and that the better elements of society are kept down by lawless characters under a system of terrorism. From my own observation I know that these things are not confined to the districts ... referred to. Both the Id. governors of Alabama and Mississippi complained of it in official proclamations.

275. Id. at 37 . 
status of blacks as freemen was fully recognized, and the capacity of local authorities to maintain order was restored. 276

At the instance of radical Republican Senator Charles Sumner of Massachusetts, the Senate obtained the Schurz report from President Johnson, and arranged for its printing and circulation. ${ }^{277}$ The report also was published in full in many newspapers throughout the country. ${ }^{278}$ Together with other accounts coming in daily from the South, 279 the Schurz report had a substantial impact on Northern public opinion and convinced many people that it was necessary for the federal government to protect the freedmen from discrimination and violence. ${ }^{280}$

In addition to Schurz's report, Congress periodically obtained from the executive branch the reports of Freedmen's Bureau officials stationed in the South. These reports, and the testimony on conditions in the South taken by the congressional Joint Committee on Reconstruction, contained evidence of extensive violence against freedmen and Unionists. ${ }^{281}$ Summarizing this testimony in its final report, the Committee wrote that the "deep-seated prejudice against color [in the South] . . . leads to acts of cruelty, oppression, and murder, which the local authorities are at no pains to prevent or punish."282

This unrestrained violence, as well as the enactment of the black codes, confirmed the Republicans' belief that the states could not be exclusively relied upon to protect the rights of citizens. Instead, they concluded that it was necessary to provide federal guarantees of protection, either through legislation or through constitutional amendment.

\section{B. The Adoption of the Civil Rights Act and the Fourteenth Amendment}

At the beginning of the Thirty-Ninth Congress, radical Republican Senator Henry Wilson of Massachusetts introduced a bill for the protection of freedmen in the South. ${ }^{283}$ The bill declared in broad terms that all laws in the southern states recognizing "any inequality of civil rights and immunities" based on race were void, and making it a misdemeanor

276. See id. at $14,45-46$.

277. See Joseph B. James, The Framing of THE Fourteenth AMENDMENT 51-52 (1956). 278. $I d$.

279. See supra text accompanying notes 265-66.

280. See FONER, supra note 264, at 224-26; JAMES, supra note 277, at 51-52.

281. See Reports of Assistant Commissioners of Freedmen's Bureau, S. Exec. Doc. No. 27, 39th Cong., 1st Sess. (1866); REPORT OF THE JOINT COMM. ON RECONSTRUCTION, H.R. REP. No. 30, 39th Cong., 1st Sess. (1860).

282. REPORT OF THE JOINT COMM. ON RECONSTRUCTION, supra note 281, at XVII.

283. For the text of the bill, see Cong. Globe, 39th Cong., 1st Sess. 39 (1865). 
to make or enforce such a law.284 Senator Wilson urged that the bill be passed immediately, to annul the black codes and to protect the freedmen from "[t]he crimes, the wrongs, [and] the outrages" that were being perpetrated against them. ${ }^{285}$ As evidence of this violence, he cited private correspondence and reports of Freedmen's Bureau officials. ${ }^{286}$

Senator Lyman Trumbull, a moderate Republican and chairman of the Judiciary Committee, responded that "[t] he bill does not go far enough, if what we have been told to-day in regard to the treatment of freedmen in the southern States is true."287 Senator Wilson's bill was based solely on the war power. ${ }^{288}$ Once the Thirteenth Amendment was ratified, Trumbull contended, congressional authority to protect the freedmen would be clear. At that time, Congress could pass "a bill that will be much more efficient to protect the freedman in his rights."289 Trumbull announced that, if no one else did, he would introduce such a bill after the Thirteenth Amendment became law. ${ }^{290}$

On January 11, 1866, Trumbull reported two bills to the Senate on behalf of the Judiciary Committee. 291 The first, a temporary measure confined to the South, was to expand the powers of the Freedmen's Bureau, an agency within the War Department that was charged with giving assistance and protection to freedmen and refugees in the south.

The second bill, which was enacted as the Civil Rights Act of 1866, was a permanent measure entitled "An Act to protect all Persons in the United States in their Civil Rights, and furnish the Means of their Vindication."292 As enacted, Section 1 declared that "all persons born in the United States" were citizens of the United States, and provided:

[S]uch citizens, of every race and color ... shall have the same right, in every State and Territory in the United States, to make and enforce contracts, to sue, be parties, and give evidence, to inherit, purchase, lease, sell, hold, and convey real and personal property, and to full and equal benefit of all laws and proceedings for the security of person and property, as is enjoyed by white citizens, and shall be subject to like punishment, pains, and penalties, and to none other, any law, statute, ordinance, regulation, or custom, to the contrary notwithstanding. ${ }^{293}$

284. See id.

285. Id. at 39.41 (remarks of Sen. Wilson).

286. See id. at 39, 41; see also id. at 111.

287. Id. at 43.

288. See id. at 39 (remarks of Sen. Wilson).

289. Id. at 43.

290. See id.

291. Id. at 184.

292. Civil Rights Act of 1866, ch. 31,14 Stat. 27 (codified at 42 U.S.C. $\S \S 1981-1982$ (1988)).

293. Id. $§ 1,14$ Stat. at 27. 
Republicans explained the Civil Rights Act in terms of natural rights theory and the classical legal tradition. "What are civil rights?" asked Representative James Wilson of Iowa, the floor manager of the bill in the House. "I understand civil rights to be simply the absolute rights of individuals."294 Following Blackstone and Kent, Wilson defined these "natural" or "absolute rights" as " "[t]he right of personal security, the right of personal liberty, and the right to acquire and enjoy property." "295 Other Republicans explained the Act in the same terms.296

In addition to natural rights, Wilson indicated, civil rights included other rights that were "necessary to complete defense and enjoyment of the specific right."297 As Representative William Lawrence of Ohio explained, these "necessary incidents of . . . absolute rights" included such rights as "the right to make and enforce contracts, to purchase, hold, and enjoy property, and to share the benefit of laws for the security of person and property." 298

Conservatives attacked the bill for invading the exclusive authority of the states to regulate the rights of citizens. ${ }^{299}$ In response, supporters argued that Congress had authority to pass the legislation under the Thirteenth Amendment. 300 Following the classical tradition, Senator Trumbull explained that "[1]iberty and slavery are opposite terms; one is opposed to the other." 301 Thus, in abolishing slavery, the Thirteenth Amendment in essence had "declared that all persons in the United States should be free."302 Under Section 2 of the Amendment, Congress had power to "give effect to that declaration and secure to all persons within the United States practical freedom," by ensuring that the former slaves possessed all of the "privileges which are essential to freemen." 303 These rights, Representative Wilson added, would be a "sure defense against efforts to reduce [blacks] to slavery." 304

294. CONG. GLOBE, 39th Cong., 1st Sess. 1117 (1860).

295. Id. (quoting $2 \mathrm{KENT}$, supra note 121, at ${ }^{*} 1$ ); see also id. at 1118 (quoting 1 BlACKSTONE, supra note 24 , at $* 129, * 134, * 138)$.

296. See, e.g., id. at 1152 (remarks of Rep. Thayer); id. at 1159 (remarks of Rep. Windom); id. at 1757 (remarks of Sen. Trumbull); id. at 1833 (remarks of Rep. Lawrence).

297. Id. at 1118-19.

298. Id. at 1833.

299. See, e.g., id. at 478 (remarks of Sen. Saulsbury); id. at 1156-57 (remarks of Rep. Thorton); id. at 1270 (remarks of Rep. Kerr).

300. Some supporters also relied on Article IV, Section 2 of the Constitution as a basis for congressional authority to enact the Civil Rights Act. This provision is discussed infra at text accompanying notes $316-32$.

301. Cong. Globe, 39th Cong., 1st Sess. 474 (1866).

302. Id.

303. Id.

304. Id. at 1118. As these arguments suggest, the Thirteenth Amendment provides another potential source for a constitutional right to protection. For an exploration of DeShaney from a 
More broadly, proponents argued that the national government had inherent authority to protect its citizens. "Allegiance and protection are reciprocal rights," asserted Senator Trumbull:

How is it that every person born in these United States owes allegiance to the Government? Everything that he is or has, his property and his life, may be taken by the Government of the United States in its defense or to maintain the honor of the nation; and can it be that ... the people of our day have struggled through a [civil] war, with all its sacrifices and all its desolation, to maintain it, and at last ... we have got a Government which is all-powerful to command the obedience of the citizen, but has no power to afford him protection? ${ }^{305}$

"American citizenship," Trumbull concluded, "would be little worth if it did not carry protection with it." ${ }^{306}$ The nation must have authority to protect fundamental rights, Representative Wilson agreed, "or our Constitution fails in the first and most important office of government."307

Republicans further argued that because the national government had the power and duty to protect the rights of its citizens abroad, it would be anomalous for it to lack that power within its own jurisdiction. "If a citizen of the United States should go abroad," stated Representative Wilson,

and while within the jurisdiction of a foreign Power be despoiled of his rights of personal security, personal liberty, or personal property contrary to the due course of law of the nation inflicting the wrong, this Government would espouse his cause and enforce redress even to the extremity of war.... [I]f all the terrible powers of war may be resorted to for the protection of the rights of our citizens when those rights are disregarded and trampled on beyond our jurisdiction, is it possible that our Constitution is so defective that we have no power under it to protect our citizens within our own jurisdiction through the peaceful means of statutes and courts? ${ }^{308}$

Most Republicans believed on these grounds that Congress had the constitutional authority to pass the Civil Rights Act. However, one leading Republican, Representative Bingham, strongly disagreed, denouncing the Act as an unconstitutional invasion of the province of the states. ${ }^{309}$ Although he believed that the national government should

Thirteenth Amendment perspective, see Akhil R. Amar \& Daniel Widawsky, Child Abuse as Slayery: A Thirteenth Amendment Response to DeShaney, 105 HARV. L. REV. (forthcoming 1992).

305. Cong. Globe, 39th Cong., 1st Sess. 1757 (1866).

306. Id.

307. Id. at 1118.

308. Id. at 1119; see also id. at 1757 (remarks of Sen. Trumbull). For further discussion of the Republican argument on the national government's inherent power of protection, see FARBER \& SHERRY, supra note 44, at 302-04.

309. See Cong. Globe, 39th Cong., 1st Sess. 1290-93 (1866). 
have the power to ensure protection of fundamental rights, Bingham argued that another constitutional amendment was necessary to give Congress such power. ${ }^{310}$ Some of the Act's supporters also admitted having doubts about its constitutionality. ${ }^{311}$ For this reason, Republicars decided to draft a constitutional amendment "to make assurance doubly sure." 312 Equally important, Republicans desired to enshrine the protections of the Civil Rights Act in the Constitution, where they would be beyond the power of a subsequent Democratic majority in Congress to repeal. ${ }^{313}$

As adopted, Section 1 of the Fourteenth Amendment provided:

All persons born or naturalized in the United States, and subject to the jurisdiction thereof, are citizens of the United States and of the State wherein they reside. No State shall make or enforce any law which shall abridge the privileges or immunities of citizens of the United States; nor shall any State deprive any person of life, liberty, or property, without due process of law; nor deny to any person within its jurisdiction the equal protection of the laws. ${ }^{314}$

It was agreed on all sides that the constitutional amendment embodied the same basic principles as the Civil Rights Act. ${ }^{315}$

\section{The Right to Protection Under the Civil Rights Act and the Fourteenth Amendment}

The 1866 debates make clear that the Framers understood the Civil Rights Act and the Fourteenth Amendment to incorporate a fundamental right to protection by the government, with a corresponding obligation on the states to afford such protection. This right was secured in different but overlapping ways by the three clauses of the Amendment's first section. Protection was a substantive right of citizenship under the Privileges or Immunities Clause. It was also implicit in the injunction that no person should be deprived of life, liberty, or property without due process of law. Finally, the Equal Protection Clause mandated that the protection afforded to a state's citizens be equal to all.

310. See id.

311. See, e.g., id. at 1293 (remarks of Rep. Shellabarger); id. at 2498 (remarks of Rep. Broomall).

312. Id. at 2498 (remarks of Rep. Broomall).

313. See id. at 2459 (remarks of Rep. Stevens); id. at 2462 (remarks of Rep. Garfield); id. at 2498 (remarks of Rep. Broomall).

314. U.S. ConsT. amend. XIV, § 1.

315. See CONG. GlobE, 39th Cong., 1st Sess. 2465 (1866) (remarks of Rep. Thayer). For other supporters, see supra note 313. For opponents, see CoNG. GloBE, 39th Cong., 1st Sess. 2467 (1866) (remarks of Rep. Boyer); id. at 2538 (remarks of Rep. Rogers). 
1. The Privileges or Immunities Clause. After declaring all persons born in the United States to be citizens, Section 1 forbids the states to "abridge the privileges or immunities of citizens of the United States." 316 For a definition of privileges and immunities, Republicans looked to a leading 1825 decision, Corfield v. Coryell. ${ }^{317}$

In Corfield, Justice Washington, sitting on circuit, was called upon to interpret Article IV, Section 2 of the Constitution, which provides that "[t]he Citizens of each State shall be entitled to all Privileges and Immunities of Citizens in the several States."318 Justice Washington held that this clause protected:

those privileges and immunities which are, in their nature, fundamental; which belong, of right, to the citizens of all free governments; and which have, at all times, been enjoyed by the citizens of the several states which compose this Union .... [T] hese fundamental principles ... may . . . be all comprehended under the following general heads: Protection by the government; the enjoyment of life and liberty, with the right to acquire and possess property of every kind, and to pursue and obtain happiness and safety; subject nevertheless to such restraints as the government may justly prescribe for the general good of the whole. ${ }^{319}$

Corfield thus recognized "[p]rotection by the government" as a fundamental right of citizenship on a par with the rights to life, liberty, and property.

Corfield was invoked by both Senator Trumbull and Representative Wilson, the managers of the Civil Rights Act, to explain the fundamental rights of citizenship secured by the Act. ${ }^{320}$ Similarly, Senator Howard, presenting the Fourteenth Amendment on behalf of the Joint Committee

316. U.S. CONST. amend. XIV, $\S 1$.

317. 6 F. Cas. 546 (C.C.E.D. Pa. 1825) (No. 3230). Corfield was discussed as the leading authority on the meaning of privileges and immunities by Chancellor Kent. See 2 KENT, supra note 121 , at $* 71-72$.

318. U.S. CONST, art. IV, $\S 2$, cl. 1.

319. 6 F. Cas. at 551-52 (emphasis added). Without attempting a complete enumeration, Justice Washington proceeded to mention "some of the particular privileges and immunities" that were regarded as fundamental, including:

[t]he right of a citizen of one state to pass through, or reside in any other state, for purposes of trade, agriculture, professional pursuits, or otherwise; to claim the benefit of the writ of habeas corpus; to institute and maintain actions of any kind in the courts of the state; to take, hold and dispose of property, either real or personal; and an exemption from higher taxes or impositions than are paid by the other citizens of the state ... to which may be added the elective franchise, as regulated and established by the laws or constitution of the state in which it is to be exercised.

Id. at 552. As we have seen, the right "to institute and maintain actions . . . in the courts" was a paradigmatic instance of the right to protection in traditional legal thought. See supra text accompanying notes $163-70$.

320. See Cong. Globe, 39th Cong., 1st Sess. 474-75 (1866) (remarks of Sen. Trumbull); id. at 1117-18 (remarks of Rep. Wilson). Another leading House Republican, William Lawrence of Ohio, also relied on Corfield for the meaning of privileges and immunities. See id. at 1835-36. 
on Reconstruction, looked to Corfield for the meaning of "privileges and immunities." 321 Thus, as John Hart Ely has observed, the Framers "repeatedly adverted to the Corfield discussion as the key to what they were writing." 322

The fundamental right to protection was emphasized by the Framers. Under Article IV, Section 2, Representative Wilson contended, "every citizen" was "entitle[d] ... to security and protection of personal rights." 323 If the states would all observe this constitutional requirement, it would be unnecessary for Congress to pass a civil rights bill. Because the states failed to comply, however, "we must do our duty by supplying the protection which the States deny." 324

In several speeches, Representative Bingham, the principal draftsman of Section 1, expressed a similar understanding. The right "to be protected in life, liberty, and property," Bingham asserted, was one of the "privileges and immunities" of citizens under Article IV, Section 2 of the Constitution. ${ }^{325}$ In common with some other Republicans, Bingham apparently believed that that provision applied to a state's treatment of its own citizens as well as of the citizens of other states. ${ }^{326}$ Thus, he declared, under the Constitution "there never was even colorable excuse ... for any man North or South claiming that any State Legislature or State court, or State Executive, has any right to deny protection to any free citizen of the United States within their limits in the rights of life, liberty, and property."327 The "want of the Republic," however, was that there was no provision in the Constitution that empowered the national government to compel states to perform their duty of protection. ${ }^{328}$ The purpose of the Fourteenth Amendment, Bingham indicated, was to remedy this deficiency by giving Congress the power "to protect by national law the privileges and immunities of all the citizens of the Republic and the inborn rights of every person within its jurisdiction

321. Id. at 2765.

322. ELY, supra note 12, at 29.

323. Cong. GloBe, 39th Cong., 1st Sess. 1118 (1866) (citing Campbell v. Morris, 3 H. \& McH. 535 (Md. 1797)).

324. Id.

325. Id. at 2542.

326. See CURTIS, supra note 127 , at $60-61,115-16$.

327. CONG. GloBe, 39th Cong., 1st Sess. 1090 (1866). Although most of Bingham's examples of state denials of protection appear to involve affirmative state deprivations, such as confiscation of property and banishment, see id. at 1090-91, he gives at least one example involving a positive right to protection: the right of "a party aggrieved in his person within a State . . to protection by prosecution of a suit, which by the organic law of the State was denied to him." Id. at 1064.

328. See id. at 1034, 2542 (remarks of Rep. Bingham). 
whenever the same shall be abridged or denied by the unconstitutional acts of any State." ${ }^{329}$

Bingham emphasized that his proposed constitutional amendment was not intended to remove from the states "the care of the property, the liberty, and the life of the citizen." 330 Instead, it was meant to give the federal government power to punish state denials of protection in violation of the states' constitutional responsibilities. ${ }^{331}$

It seems clear, then, that protection was understood to be one of the principal rights of citizenship encompassed by the Privileges or Immunities Clause. This simply reflected the classical view of the relationship between citizenship and protection. As Representative Lawrence expressed it, "citizenship implies certain rights which are to be protected," in return for "the duty of allegiance and obedience to the laws." 332

2. The Due Process Clause. As we have seen, the substantive rights to be secured by the Civil Rights Act and the Fourteenth Amendment were discussed primarily in terms of the privileges and immunities of citizenship. The Privileges or Immunities Clause, however, was rendered virtually a dead letter by the Slaughter-House Cases. ${ }^{333}$ When the Supreme Court, beginning in the late nineteenth century, expanded its interpretation of the Fourteenth Amendment to include substantive rights, it relied not on that clause, but on the Due Process Clause. Thus, the controversy in DeShaney focused on the Due Process Clause. In rejecting a constitutional duty of protection, Chief Justice Rehnquist relied on both the history and the language of that provision. ${ }^{334}$ Properly read, however, both of these sources support a right to protection under the Due Process Clause.

The history of the Due Process Clause sheds crucial light on its meaning. As the congressional debates reveal, the clause was understood to have a positive dimension. Referring to the Due Process Clause of the Fifth Amendment, which was to be incorporated into the Fourteenth, Representative Bingham stated that the Clause ensured "the protection of the laws"; ${ }^{335}$ it guaranteed the right "of all persons to be protected in

329. Id. at 2542.

330. Id. at 1090, 1292.

331. See id. In these statements, Bingham was talking about an earlier version of the proposed amendment. His remarks, however, seem equally applicable to the version of the Fourteenth Amendment that was finally adopted.

332. Id. at 1832.

333. 83 U.S. (16 Wall.) 36 (1873).

334. See supra text accompanying notes 3-5.

335. Cong. GlobE, 39th Cong., 1st Sess. 1292 (1866). 
life, liberty, and property." 336 Hence, it was a violation of the Due Process Clause for any state "to deny protection to any free citizen of the United States within their limits in the rights of life, liberty, and property."337 This positive understanding of the Due Process Clause was also expressed by other members. ${ }^{338}$

This identification of the Due Process Clause with the right to protection of the law was not, as is often thought, ${ }^{339}$ peculiar to Republican or antislavery ideology. Instead, it was central to the classical understanding of "due process of law" or "the law of the land" in both England and America.

The Due Process Clauses of the Federal Constitution trace back to chapter 29 of Magna Carta, which declared: "No Freeman shall be taken, or imprisoned, or be disseised of his Freehold, or Liberties, or free Customs, or be outlawed, or exiled, or any otherwise destroyed; nor will [the sovereign] pass upon him, nor condemn him, but by lawful Judgment of his Peers, or by the Law of the Land."340 Most of the first state constitutions contained "law of the land" provisions based on this clause of Magna Carta. ${ }^{341}$ In drafting the Fifth Amendment, Madison translated the medieval language of Magna Carta into the modern terminology of life, liberty, and property. ${ }^{342}$ It was generally agreed, however, that there was no substantive difference between the ancient and modern

336. Id. at 1089.

337. Id. at 1090 .

338. See, e.g., id. at 1152 (remarks of Rep. Thayer) (asserting that the Fifth Amendment "guaranties to all the citizens of the United States their right to life, liberty, and property"); id. at 1294 (remarks of Rep. Wilson) (stating that under the Fifth Amendment "[t]he citizen is entitled to life, liberty, and the right to property"); see also id. at 227 app. (remarks of Rep. DeFrees) (contending that Section 1 of the Fourteenth Amendment "secures to all life, liberty, and property").

339. See, e.g., William W. Crosskey, Charles Fairman, "Legislative History," and the Constitutional Limitations on State Authority, 22 U. CHI. L. REV. 1, 16-17 (1954).

340. Magna Carta ch. 29 (1225) (Eng.), 1 Stat. at Large 7-8 (London, 1763) (emphasis omitted).

341. See, e.g., MASS. CONST. of 1780 , pt. I, art. XII, reprinted in 5 STATE CONSTITUTIONS, supra note 13, at 94; VA. DEClaRATION OF RIGHTS of 1776 \& 8, reprinted in 10 STATE ConstituTIONS, supra note 13, at 49.

342. See ADAMS, supra note 79, at 157 (describing American translation of medieval constitutional language into modern natural rights concepts). 
forms of the provision. ${ }^{343}$ By the time of the Civil War, the provision appeared in some form in virtually every state constitution. ${ }^{344}$

In his Commentaries, Blackstone treated chapter 29 of Magna Carta as having positive content. That provision, he wrote, "protected every individual of the nation in the free enjoyment of his life, his liberty and his property, unless declared to be forfeited by the judgment of his peers or the law of the land."345 This view was echoed by Daniel Webster in his argument in the Dartmouth College case ${ }^{346}$ - the most widely quoted antebellum definition of "the law of the land" or "due process of law."347 "By the law of the land," he declared, "is most clearly intended, the general law; a law, which hears before it condemns; which proceeds upon inquiry, and renders judgment only after trial. The meaning is, that every citizen shall hold his life, liberty, property and immunities, under the protection of the general rules which govern society." ${ }^{348}$

Thus, Webster and Blackstone both described the law-of-the-land clause as requiring protection in life, liberty, and property. Read narrowly, these statements might be taken to refer only to protection against intrusions by the government itself. Understood in the context of classical thought, however, the principle that they articulated had broader meaning. A citizen holds his life, liberty, and property under the protection of the law. The law secures rights on one hand, and specifies the conditions under which those rights are forfeited on the other. The due process or law-of-the-land provisions bar the government from depriving a citizen of his rights except under the conditions set forth by law, ascertained through a judicial proceeding. In the absence of a judicially determined forfeiture, the citizen is entitled to the protection of the law, including the right to appeal to the law for redress of any injuries he

343. See Murray's Lessee v. Hoboken Land \& Improvement Co., 59 U.S. (18 How.) 272, 276 (1855); Cooley, supra note 104, at *351-53; Robert E. Riggs, Substantive Due Process in 1791, 1990 WIS. L. REV. 941, 991-95.

Bingham viewed the Fifth Amendment as expanding the coverage of Magna Carta. See CoNG. GlOBE, 39th Cong., 1st Sess. 1292 (1866) (remarks of Rep. Bingham) (The Framers of the Fifth Amendment "abolished the narrow and limited phrase of the old Magna Carta . . ., which gave the protection of the laws only to 'free men,' and inserted instead the more comprehensive words, 'no person." ").

344. See COOLEY, supra note 104 , at $* 351-53$ \& n.1 (citing provisions).

345. 4 BLACKSTONE, supra note 24 , at $* 424$. In addition, Blackstone observed that the reference to "outlawry" in chapter 29 meant that no freeman could be "put out of the protection and benefit of the laws, [except] according to the law of the land." 1 id. at *141.

346. Trustees of Dartmouth College v. Woodward, 17 U.S. (4 Wheat.) 518, 551-99 (1819) (argument of Daniel Webster for plaintiffs in error).

347. See COOLEY, supra note 104, at *353. The Supreme Court adopted Webster's language in Hurtado v. California, 110 U.S. 516, 535-36 (1884).

348. Dartmouth College, 17 U.S. (4 Wheat.) at 581 (emphasis added). 
might suffer, whether from private parties or from the government itself. 349

Leading mid-nineteenth-century writers followed Blackstone and Webster in identifying due process or law-of-the-land provisions with the right to protection. ${ }^{350}$ Reflecting this view, some antebellum judicial opinions determined that a state might violate these provisions not only by directly taking life, liberty, or property, but also by denying legal protection to an individual or his rights. As one judge expressed it:

[To hold] that the [due process] clause can apply only to cases where there is to be some manual interference [by the state] with the rights of person or of property ... would virtually nullify the provision, as the most oppressive and tyrannical ends may be accomplished by simply withdrawing from individual rights the protection of the law. ${ }^{351}$

Thus, it was held that the clause was violated by legislation that denied a class of persons the right to sue in court, ${ }^{352}$ or that denied all legal remedy for the violation of an existing right. ${ }^{353}$ Articulating the general principle underlying these cases, Thomas M. Cooley wrote that "every

349. See id. at $569-70$.

350. For example, Theodore Sedgwick, in his influential treatise on statutory and constitutional interpretation, wrote that the clause "guarantees to life, liberty, and property the protection of law." Theodore SEDGWick, A Treatise on the Rules Which Govern the INTERPRETATION AND CONSTRUCTION OF STATUTORY AND CONSTITUTIONAL LAW 534 (1857). Sedgwick's identification of due process with the right to protection is further reflected by the fact that the entry in the table of contents corresponding to the due process clause is "Protection of Law." Id. at xi.

Similarly, in his Constitutional Limitations, Thomas M. Cooley wrote that the due process clauses guaranteed "[t]he protection of the subject in the free enjoyment of his life, his liberty, and his property, except as they might be declared by the judgment of his peers or the law of the land to be forfeited." COOLEY, supra note 104, at *351. Cooley's treatise was published in 1868, the same year that the Fourteenth Amendment was ratified.

351. Wynehamer v. People, 13 N.Y. 378, 434 (1856) (opinion of Selden, J.).

352. See Wally's Heirs v. Kennedy, 10 Tenn. (2 Yer.) 554 (1831). The same result was reached under state constitutional provisions guaranteeing the right to a remedy for injuries. See, e.g., Davis v. Pierse, 7 Minn. 13 (1862); supra text accompanying notes 166-68 (discussing these provisions).

353. See Newland v. Marsh, 19 Ill. 376, 383-84 (1857); Wynehamer v. People, 13 N.Y. 378 (1856). The best known case is Wynehamer, which held that a New York statute prohibiting the sale of intoxicating liquor violated the due process clause of the state constitution. Although the case focused on the constitutionality of prohibition laws, it also raised the issue whether a state could deny all remedies for an injury to an existing property right. Section 16 of the statute effectively denied the owner of liquor a remedy if it was taken or injured by others. The intermediate court held that this provision violated the state due process clause by impairing "the right to protection of the laws, and to redress by the legal tribunals." People v. Berberrich, 11 How. Pr. 289, 320-21 (N.Y. Sup. Ct. 1855) (opinion of Brown, J.), aff'd sub nom. Wynehamer v. People, 13 N.Y. 378 (1856). Several of the leading opinions in the court of appeals also relied in part on this denial of protection in holding the statute unconstitutional. See Wynehamer, 13 N.Y. at 396, 397, 399 (opinion of Comstock, J.); id. at 423 (opinion of A.S. Johnson, J.); see also id. at 434 (opinion of Selden, J.) (quoted supra text accompanying note 351). Two other courts reached the same conclusion, relying on state constitutional guarantees of the right to a remedy. See Preston v. Drew, 33 Me. 558 (1852); Opinion of the Justices, 25 N.H. 537, 540 (1852). 
man is entitled to a certain remedy in law for all wrongs against his person or his property." 354

Thus, the contemporary understanding of the due process clause was not limited to direct governmental takings of life, liberty, and property. Instead, that clause was understood in the antebellum legal tradition to guarantee these rights the protection of the laws. As the congressional debates show, this understanding was shared by the Framers of the Fourteenth Amendment.

We may now return to the language of the Due Process Clause as it appears in the Fourteenth Amendment. The Clause, Chief Justice Rehnquist argued,

is phrased as a limitation on the State's power to act, not as a guarantee of certain minimal levels of safety and security. It forbids the State itself to deprive individuals of life, liberty, or property without 'due process of law,' but its language cannot fairly be extended to impose an affirmative obligation on the State to ensure that those interests do not come to harm through other means. ${ }^{355}$

Although on the surface this interpretation seems very powerful, it fundamentally distorts the meaning of the Due Process Clause by abstracting the language from its historical context. When the Clause is read in light of the contemporary legal understanding, a different meaning emerges.

First, as the congressional debates indicate, when the Framers referred to "life, liberty [and] property," they principally meant the rights to life, liberty, and property. ${ }^{356}$ They identified these rights with "the absolute rights" of individuals recognized in the classical legal tradition:

The Wynehamer decision was widely known. The intermediate court's decision was discussed with approval by Sedgwick, including the holding that the denial of a remedy impaired "the right of protection belonging to the citizen." SEDGwICK, supra note 350, at 481 .

Wynehamer's broader holding that prohibition laws were unconstitutional was rejected by most other state courts. See CoOLEY, supra note 104 , at $* 582-83$ \& n.3 (citing cases). These decisions did not disagree with the view that the due process clause would be violated by denying all remedy for the violation of a valid property right. Instead, they held that in the exercise of the police power, the state could legitimately abolish or restrict the substantive right to property in liquor.

354. COOLEY, supra note 104 , at $* 362$. Several decades later, the Supreme Court endorsed the view that the Due Process Clause of the Fourteenth Amendment included a right to protection. In Truax v. Corrigan, 257 U.S. 312 (1921), Chief Justice Taft wrote:

The due process clause requires that every man shall have the protection of his day in court, and the benefit of the general law, ... so that every citizen shall hold his life, liberty, property and immunities under the protection of the general rules which govern society. [The due process clause] makes a required minimum of protection for every one's right of life, liberty, and property, which the Congress or the [State] Legislature may not withhold. Id. at 332 (citation omitted). For discussion of Truax, see Currie, supra note 104, at 876-78.

355. DeShaney v. Winnebago County Dep't of Social Servs., 489 U.S. 189, 195 (1989).

356. See, e.g., CoNG. GLOBE, 39th Cong., 1st Sess. 475 (1866) (remarks of Sen. Trumbull); id. at $1089-90$ (remarks of Rep. Bingham); id. at 1117-18 (remarks of Rep. Wilson); id. at 1833, 1835 (remarks of Rep. Lawrence); id. at 3036 (remarks of Sen. Henderson). 
the rights to personal security, personal liberty, and private property. ${ }^{357}$ As we have seen, these rights were understood in the legal tradition not merely as negative rights against invasion by others, but also as positive rights to the security of life, liberty, and property under the law. ${ }^{358}$

Moreover, in traditional legal terminology, the term "deprive" may mean not only to take away a possession, but also to divest of a right. For example, the Virginia Declaration of Rights asserted that "all men ... have certain inherent rights, of which, when they enter into a state of society, they cannot, by any compact, deprive or divest their posterity."359

Understood in this way, the Due Process Clause forbids the state to deprive any person of the rights to life, liberty, and property, that is, of security in those rights under the law. Of course, the state would violate this provision by executing or imprisoning a person, or by taking his property, without due process. But it would do so as well by refusing to protect a person in life, liberty, or property, thereby depriving him of security against the invasion of those rights by others. As Representative Lawrence explained, "there are two ways in which a State may undertake to deprive citizens of [their] absolute, inherent, and inalienable rights: either by prohibitory laws, or by a failure to protect any one of them."360

An alternative (but not necessarily inconsistent) interpretation of the Due Process Clause leads to the same conclusion. The Clause expressly forbids state deprivations of the absolute rights of life, liberty, and property. As Lawrence explained, however, whenever the law gives a right, it also gives "the means whereby [the right] may be possessed and enjoyed."361 Thus, as Chairman Wilson argued, the Due Process Clause may be understood to encompass not only these absolute rights but also "those which are necessary for the protection and maintenance and perfect enjoyment of the rights thus specifically named."362 As we have

357. Id. at 1833 (remarks of Rep. Lawrence); see also id. at 1117-18 (remarks of Rep. Wilson); id. at 1757 (remarks of Sen. Trumbull).

358. See supra text accompanying note 153.

359. VA. CONST. of 1776, Bill of Rights $\S 1$, reprinted in 10 STATE CONSTITUTIONS, supra note 13, at 49 (emphasis added).

360. CoNG. GloBE, 39th Cong., 1st Sess. 1833 (1866) (emphasis added). Lawrence's reference to "prohibitory laws" reflects the Thirty-Ninth Congress's predominant concern with the threat posed by the newly enacted black codes. Of course, the Fourteenth Amendment has long been interpreted to apply to all state action, not only legislation. See, e.g., Yick Wo v. Hopkins, 118 U.S. 356, 371-72 (1886).

361. CoNG. GloBE, 39th Cong., Ist Sess. 1833 (1866). Lawrence quoted from Coke's Reports the legal maxim that where " the law granteth anything to any one that also is granted without which the thing itself cannot be.' " Id. (quoting Oath Before the Justices, 12 Co. Rep. 130, 130, 77 Eng. Rep. 1405, 1405 (1612)).

362. Id. at 1294 . 
seen, the Framers believed that the right "to share the benefit of laws for the security of person and property" was among the "necessary incidents" of the three absolute rights. ${ }^{363}$ Accordingly, state deprivation of that right violates the Due Process Clause. This interpretation is consistent with the Framers' understanding that the Fourteenth Amendment constitutionalized the Civil Rights Act; 364 that Act, as we shall see, expressly guaranteed the right to share in the benefit of laws for the security of person and property. ${ }^{365}$

3. The Equal Protection Clause. The Equal Protection Clause expressly recognizes a right to the "protection of the laws," but qualifies it with the term "equal." It could be argued that the Fourteenth Amendment does incorporate a right to protection, but only to "equal" protection. On this view, the state need not grant protection to anyone; if it chooses to do so, however, it must afford protection to all citizens on an impartial basis, without regard to race or other suspect criteria. ${ }^{366}$

There are two responses to this line of argument. First, although the Equal Protection Clause, taken by itself, may not establish a substantive right to protection, that does not mean that the Fourteenth Amendment as a whole does not confer such a right. As we have seen, the principal source of substantive rights in the Amendment was the Privileges or Immunities Clause. Protection was clearly regarded as among the basic privileges of American citizenship. Thus, the Privileges or Immunities and the Equal Protection Clauses are perfectly complementary. The former confers a substantive right to protection, whereas the latter requires that the protection given to all citizens be equal.

More fundamentally, the argument misunderstands the concept of equality in Reconstruction-era thought. Equality was not sharply distinct from the substantive rights to liberty and protection, but was essentially connected with them. At its most basic level, equality meant being fully recognized as a freeman and a citizen, with all the rights and obligations corresponding to that status.

The foundations of equal protection may be found, in part, in Lockean thought. 367 Locke begins, as we have seen, with the idea of natural

363. Id. at 1833 (remarks of Rep. Lawrence); see supra text accompanying notes 297-98.

364. See supra text accompanying notes 313,315 .

365. See infra text accompanying notes $382-402$.

366. Judge Posner suggests this position in several of his opinions. See, e.g., Jackson v. City of Joliet, 715 F.2d 1200, 1203 (7th Cir. 1983); Bowers v. DeVito, 686 F.2d 616, 618 (7th Cir. 1982). For a similar view, see RAOUL BERGER, GOVERNMENT BY JUdiciary: THE TRANSFORMATION OF THE FOURTEENTH AMENDMENT 176-83 (1977).

367. For another account of the relationship between equal protection and natural rights theory, see Hamburger, supra note 128. 
liberty. ${ }^{368}$ In a state of nature, every man is free to direct his own actions, without depending on the will of any other man. Men who are free in this way are also equal because each is independent of the others. Locke defines natural equality in two ways. In negative terms, it means the absence of "Subordination or Subjection," whereby an individual is deprived of his natural freedom and subjected to the will of another. ${ }^{369}$ In positive terms, natural equality means the equal right to one's natural liberty. ${ }^{370}$ As Locke explains, although men differ in ability, age, and virtue,

yet all this consists with the Equality, which all Men are in, in respect of Jurisdiction or Dominion one over another, which was the Equality I . . . spoke of, . . . being that equal Right that every Man hath, to his Natural Freedom, without being subjected to the Will or Authority of any other Man. ${ }^{371}$

When men enter civil society, they give up their natural liberty in return for protection. ${ }^{372}$ Just as natural equality was the equal right to natural liberty, civil equality is the equal right to protection under the law. ${ }^{373}$ Thus, Locke writes that the members of society are "equally Subjects of the same Law together," a law that is "common to every one of that Society," and that secures the natural rights of all its members. ${ }^{374}$

For Locke, the concept of equality has crucial substantive implications. It gives rise to one of the most basic principles of the law of nature: "[T]hat being all equal and independent, no one ought to harm another in his Life, Health, Liberty, or Possessions." 375 To harm another denies equality because it treats him as subordinate to my will and infringes his equal right to liberty. ${ }^{376}$ It follows that for the law to treat persons as equals, it must protect each individual against the invasion of his rights by others.

In sum, Locke implies that every individual has an equal right to protection under the law. This right has a substantive as well as a formal

368. See LockE, supra note $25, \S 4$.

369. Id.

370. See id. § 54.

371. $I d$.

372. Id. $\S \S 131,136$.

373. As we have seen, legal writers such as Blackstone and Kent identified liberty with protection. See supra Part I(C). In these terms, it may be said that, just as natural equality is the equal right to natural liberty, civil equality is the equal right to civil liberty, i.e., the equal right to protection.

374. LOCKE, supra note $25, \S \S 22,59,131$; see also id. $\S 142$ (The legislative power must "govern by promulgated establish'd laws, not to be varied in particular Cases, but to have one Rule for Rich and Poor, for the Favourite at Court, and the Country Man at Plough.").

375. Id. § 6.

376. Id. For another good statement of this view, see JAMES WiLSON, Lectures On Law (17901791), reprinted in 1 THE WORKS OF JAMES WILSON, supra note 73, at 241. 
dimension: It requires not only that the law apply equally to all, but also that the law protect individuals against violation of their rights by others.

This understanding of equality was shared by the Framers of the Fourteenth Amendment, a point that was brought out most clearly in an exchange between Senators Henry Wilson of Massachusetts and Edgar Cowan of Pennsylvania during the Senate's consideration of the Freedmen's Bureau Bill. ${ }^{377}$ Responding to a challenge by Senator Cowan, Senator Wilson replied:

Sir, the Senator from Pennsylvania asks me what I mean by the equality of men .... He asks whether I mean that one man shall weigh as much as another, or have as much money. Why are these questions put? Does he not know precisely and exactly what we do mean? Does he not know that we mean that the poorest man, be he black or white, that treads the soil of this continent, is as much entitled to the protection of the law as the richest and the proudest man in the land? ? $^{378}$

In identifying equality with protection, Senator Wilson was simply articulating the common view, expressed by supporters and opponents alike. ${ }^{379}$ Indeed, Senator Cowan himself had defined equality earlier in the debate in almost identical terms:

What is meant by equality, as I understand it, in the language of the Declaration of Independence, is that each man shall have the right to pursue in his own way life, liberty, and happiness. That is the whole of it. It is not that he shall be an elector, it is not that he shall receive the especial favors of the community in any way; but it means that if he is assailed by one stronger than himself the Government will protect him to punish the assailant. It means ... that if an intruder and trespasser gets upon his land he shall have a remedy to recover it. That is what I understand by equality before the law. .380

As the exchange between Wilson and Cowan shows, equality was not merely a formal or "empty"381 concept to the Framers, but an essential correlate of the substantive rights to liberty and protection. By equality, the Framers meant the equal right of every individual to protection in his natural rights of life, liberty, and the pursuit of happiness.

377. CONG. GLOBE, 39th Cong., 1st Sess. 342-43 (1866).

378. Id. at 343.

379. In addition to the statements of Senators Wilson and Cowan, quoted in the text, see $i d$. at 1293 (remarks of Rep. Shellabarger) ("Innumerable authorities might be produced to show a selfevident thing, that protection by his Government is the right of every citizen, and that this right to protection is equal to all citizens ...."); id. at 2539 (remarks of Rep. Farnsworth) ("How can [an individual] have and enjoy equal rights of 'life, liberty, and the pursuit of happiness' without 'equal protection of the laws"?"); id. at 2962 (remarks of Sen. Poland) ("All the people, or all the members of a State or community, are equally entitled to protection; they are all subject to its laws; they must all share its burdens, and are all interested in its legislation and government.").

380. Id. at 342 .

381. See Peter Westen, The Empty Idea of Equality, 95 Harv. L. Rev. 537 (1982). 
Protection, in turn, was a fundamental right, not a mere benefit that the state could arbitrarily bestow or withhold. Understood in this way, "equal protection" was not a limited form of protection, a right to merely equal rather than to full protection; instead, it meant the equal right of every person to the protection that states owe to their citizens.

\section{The Meaning of Protection}

The final issue concerns the content or meaning of the constitutional right to protection. This meaning may be gathered not only from the 1866 debates, but also from the provisions of the Civil Rights Act, which gave concrete legal expression to the concepts that were embodied in the Fourteenth Amendment. As we have seen, constitutionalizing the Civil Rights Act was a major purpose of the Fourteenth Amendment. 382 These sources show that the Framers understood protection in the same way that the concept was understood in the classical legal tradition.

The Framers sought to secure protection in the three senses in which the term was traditionally understood. ${ }^{383}$ First, the most basic purpose of the Thirteenth and Fourteenth Amendments was to recognize the newly freed slaves as freemen and as citizens-persons entitled to protection of the law as members of the community. ${ }^{384}$ Second, the Framers sought to ensure substantive recognition of the absolute rights of individuals to life, liberty, and property. These rights were secured by the Privileges or Immunities Clause and by the Due Process Clause. Finally, the debates and the Civil Rights Act show that the Framers understood protection to include the enforcement of legal rights by government. In this sense, protection included civil protection, criminal protection, and the prevention of injury by peace officers.

1. Civil Protection. For the Framers, "the right to protection by the prosecution of a suit, ... . either for the vindication of a right or the redress of a wrong," 385 was a central instance of the right to protection. In Corfield, Justice Washington had mentioned the right "to institute and maintain actions of any kind in the courts of [a] state" as one of the particular privileges and immunities of citizens-a privilege evidently falling under the general category of "[p]rotection by the government." 386 Following Corfield, Senator Trumbull declared that "the right

382. See supra text accompanying note 313.

383. See supra Part II.

384. See Kaczorowskj, supra note 250, at 898-99; see also West, supra note 52 (arguing that the positive liberties of autonomy and citizenship were at the core of the Fourteenth Amendment).

385. CONG. GLOBE, 39th Cong., 1st Sess. 1064 (1866) (remarks of Rep. Bingham).

386. Corfeld v. Coryell, 6 F. Cas. 546, 551-52 (C.C.E.D. Pa. 1825) (No. 3230) (quoted supra in note 319). In addition to Corfield, Republicans cited state decisions such as Clarke v. Morey, 10 
to enforce rights in the courts" was one of "the great fundamental rights ... appertaining to every freeman" set forth in the Civil Rights Act. ${ }^{387}$ As Senator Sherman put it: "To say that a man is a freeman, and yet is not able to assert and maintain his right, in a court of justice, is a negation of terms." 388

The right to civil redress clearly was encompassed by Section 1 of the Act, which expressly secured the rights "to sue [and] be parties."389 Although these rights might be purely procedural, the substantive right to a remedy for injuries was protected by the guarantee of "full and equal benefit of all laws and proceedings for the security of person and property." 390

2. Criminal Protection. In common with the legal tradition, the Framers also understood the right to protection to include the right to share in the benefit of criminal laws for the security of life, liberty, and property. This understanding was expressed most clearly by Senator Cowan, a conservative Republican opponent of the Fourteenth Amendment. Although he rejected granting citizenship to non-whites, Senator Cowan acknowledged that they had a right to protection. Even an alien, he stated,

is entitled, to a certain extent, to the protection of the laws. You cannot murder him with impunity. It is murder to kill him, the same as it is to kill another man. You cannot commit an assault and battery on him, I apprehend. He has a right to the protection of the laws; but he is not a citizen in the ordinary acceptation of the word..$^{391}$

Other members also understood the concept of protection to include criminal protection..$^{392}$

It seems clear that the right to criminal protection was included within the Civil Rights Act's guarantee of "full and equal benefit of all

Johns. 71 (N.Y. 1813), in which then-Chief Justice Kent held that this right belonged even to enemy aliens lawfully present in the state: "A lawful residence implies protection, and a capacity to sue and be sued." Id. at 72 (quoted in CoNG. GLOBE, 39th Cong., 1st Sess. 1757 (1866) (remarks of Sen. Trumbull)).

387. Cong. GLoBE, 39th Cong., 1st Sess. 475 (1866).

388. Id. at 41 ; see also id. at 1160 (remarks of Rep. Windom) ("Is he free who cannot bring a suit in court for the defense of his rights?").

389. Civil Rights Act of 1866, § 1, 42 U.S.C. § 1981 (1988).

390. Id.

391. CoNG. GLOBE, 39th Cong., 1st Sess. 2890 (1860) (remarks of Sen. Cowan); see also id. ("So far as the courts and the administration of the laws are concerned, I have supposed that every human being within their jurisdiction was in one sense of the word a citizen, that is, a person entitled to protection ....").

392. For Republicans who made statements reflecting this understanding, see, for example, id. at 1292 (remarks of Rep. Bingham); id. at 1295 (remarks of Rep. Wilson); id. at 1833, 1835-36 (remarks of Rep. Lawrence). For Democrats, see, for example, id. at 479-80 (remarks of Sen. Saulsbury). 
laws and proceedings for the security of person and property." 393 In the legal tradition, the enactment and enforcement of criminal laws was recognized as one of the principal means of assuring the security of person and property. ${ }^{394}$ Throughout the session, Republicans denounced the violence against freedmen and loyalists in the South and the inability or unwillingness of local authorities to suppress it, and stressed the urgent need for Congress to respond. ${ }^{395}$ The Act's opponents, on the other hand, attacked it for invading what they regarded as the states' exclusive responsibility for protecting citizens against criminal offenses. ${ }^{396}$ In response, supporters demanded to know whether the national government was powerless to protect its own citizens where states "undertake to authorize such offenses, or deny to a class of citizens all protection against them." 397 Senator Trumbull also implied that the right to criminal protection was covered by the Act. 398 It appears, therefore, that there was a general understanding that the right to protection under the criminal laws was secured by the Act.

The Act also expressly secured another right that was closely connected to civil and criminal protection-the right to give evidence. ${ }^{399}$ The rationale for this provision was brought out in a colloquy between Representative Wilson and Representative Columbus Delano of Ohio, a conservative Republican opposed to the Act. ${ }^{400}$ Challenged by Delano to explain how the right to testify could be considered "a necessary incident to freedom," Wilson responded that testimony might be "necessary to be given in court for the protection of life, liberty, and property."401 Other

393. Civil Rights Act of $1866, \S 1,42$ U.S.C. $\S 1981$ (1988).

394. See supra text accompanying notes 171-84.

395. See, e.g., ConG. Globe, 39th Cong., 1st Sess. 339, 373 (1866) (remarks of Sen. Creswell); id. at 340 (remarks of Sen. Wilson); id. at 631, 633 (remarks of Rep. Moulton); id. at 656-58, 2774 77 (remarks of Rep. Eliot); id. at 1008 (remarks of Rep. Clarke); id. at 1017-19 (remarks of Rep. Beaman); id. at 1799 (remarks of Sen. Wade); id. at 1833-35 (remarks of Rep. Lawrence); see also supra text accompanying notes 283-90.

396. See, e.g., Cong. Globe, 39th Cong., 1st Sess. 479 (1860) (remarks of Sen. Saulsbury); id. at 1292 (remarks of Rep. Bingham).

397. Id. at 1835 (remarks of Rep. Lawrence) (emphasis added).

398. In a speech urging that President Johnson's veto of the Act be overridden, Trumbull quoted several military orders for the protection of the freedmen, including one that provided: "All injuries to the person or property committed by or upon freed persons shall be punished in the manner provided by the laws of [this state] for like injuries to the persons or property of citizens thereof." Id. at 1759 (quoting military orders issued by Major General Sickles on June 17, 1866) (emphasis added). Trumbull remarked that these military orders embodied "the very provisions of this bill." Id.

399. See Civil Rights Act of $1866, \S 1,42$ U.S.C. $\S 1981$ (1988).

400. See Cong. Globe, 39th Cong., 1st Sess. 158 app. (1866) (remarks of Reps. Delano and Wilson).

401. Id. 
supporters agreed, stressing that the right to testify was necessary to punish offenses committed against loyalists, blacks, and other minorities. ${ }^{402}$

3. Prevention of Injury. In its final report on the Fourteenth Amendment, the Joint Committee on Reconstruction criticized the failure of local authorities in the South to "prevent or punish" offenses against blacks. ${ }^{403}$ That the right to protection was understood to include the prevention of violence by peace officers is made clear by the congressional response to the Memphis riot of 1866.

The Memphis riot began with an altercation between white police and recently discharged black soldiers on May 1, 1866, which led to three days of mob violence by whites. At least forty-six blacks were killed and over one hundred homes, churches, and schoolhouses belonging to blacks were destroyed. ${ }^{404}$ Word of the massacre reached Washington a few days later, on the eve of House approval of the Fourteenth Amendment. ${ }^{405}$ The Republican leader, Thaddeus Stevens, denounced the "atrocity" during the final House debate on the Amendment. 406 Soon thereafter, the House voted, on Stevens's motion, to dispatch a select committee to Memphis to investigate the riot. ${ }^{407}$

The committee's report found that the mob had been led by the city's recorder and many of its policemen, and thus had "the sanction of official authority."408 The committee clearly indicated its view, however, that the civil authorities had a duty not merely to avoid participating in violence, but to protect against it, as "the chosen guardians of the public peace, the sworn executors of the law for the protection of the lives, liberty, and property of the people, and the reliance of the weak and defenceless in time of danger ...."409 The report criticized the civil authorities, including the mayor and sheriff, for their failure to suppress

402. For example, Representative Lawrence agreed with an editorial in favor of the right to testify that gave the example of "a riotous white attack on a colored school kept by a white woman." Id. at 1833. Similarly, Senator John Conness of California contended that the provision was necessary because of laws such as those of his own state, which prohibited Chinese persons from testifying. The result of these laws, he stated, was that the Chinese had been robbed and murdered "with impunity, for if a white man was not present no one could testify against the offender." Id. at 2892.

403. See REPORT OF THE JoINT COMM. ON RECONSTRUCTION, supra note 281, at XVII.

404. See REPORT ON MEMPHIS RIOTS AND MASSACRES, H.R. REP. No. 101, 39th Cong., 1st Sess. 6-22, 34-36 (1866); FONER, supra note 264, at 261-62.

405. See Cong. Globe, 39th Cong., 1st Sess. 2544 (1866) (remarks of Rep. Stevens).

406. Id.

407. Id. at 2572.

408. REPORT ON MEMPHIS RIOTS AND MASSACRES, supra note 404, at 34.

409. Id. 
the riot, as well as for their failure to take any steps to bring the perpetrators to justice. ${ }^{410}$ These failures were instances of a more general denial of justice. Blacks, the committee reported,

have had no protection from the law whatever. All the testimony [taken by the committee] shows that it was impossible for a colored man in Memphis to get justice against a white man. Such is the prejudice against the negro that it is almost impossible to punish a white man by the civil courts for any injury inflicted upon a negro. ${ }^{411}$

The committee concluded that neither blacks nor white Unionists would be safe in Memphis without the presence of federal troops "to uphold the authority of the government, and protect the lives, liberty, and property of citizens of the United States." 412

The committee submitted its report to the House on July 18, 1866, only six weeks after final congressional approval of the Fourteenth Amendment. ${ }^{413}$ In effect, the committee report was endorsed by the House, which voted to print the report over Democratic opposition. 414

The congressional response to the Memphis riot-a response that was virtually contemporaneous with Congress's approval of the Fourteenth Amendment-confirms that the Framers understood the duty of protection to include protection against private violence. Moreover, it shows that this duty was understood to include the responsibility of government to prevent violence, not merely to remedy or to punish it after it occurred.

\section{ConClusion}

In DeShaney, the Supreme Court held that states have no constitutional duty to protect their citizens against private violence. In this Article, I have sought to challenge DeShaney on its own terms-the original understanding of the Fourteenth Amendment.

As I have argued, the right to protection was a central doctrine of American constitutionalism prior to the Civil War. This doctrine, rooted in the common law tradition and social contract theory, held that the most basic obligation of government was to protect individuals against

410. See id. at 23-25, 27.

411. Id. at 30.

412. Id. at 27 .

413. Cong. Globe, 39th Cong., 1st Sess. 3905 (1866).

414. Id. at 4159. The vote on the motion was 85-23. The House subsequently voted to print more than 10,000 extra copies, probably, as Democrats charged, with a view to the fall elections. Id. at 4159, 4264-66. The Memphis riot, together with an even more serious outbreak of violence in New Orleans 12 weeks later, in fact played an important role in the 1866 elections by discrediting President Johnson's Reconstruction policy. See FONER, supra note 264, at 262-63. In addition, Republicans pointed to the Memphis and New Orleans massacres in arguing for state ratification of the Fourteenth Amendment. See CuRTIS, supra note 127, at 159. 
violence. The right to protection was not merely a matter of constitutional theory, but had concrete legal meaning.

Under the original Constitution, the responsibility for protecting life, liberty, and property was left largely to the states. The history of slavery and suppression in the South before the War, together with the torrent of violence against blacks and Unionists after the War, convinced most Republican members of the Thirty-Ninth Congress that the states could not be relied upon to protect the rights of all persons. In response, the Republicans secured the adoption of the Civil Rights Act of 1866 and the Fourteenth Amendment. A central purpose of both measures was to incorporate the right to protection into the Federal Constitution, and thereby to empower the national government to compel the states to fulfill their duty of protection.

Protection was one of the most basic rights of citizenship secured by the Privileges or Immunities Clause. It was also implicit in the Due Process Clause, which the classical tradition identified with the right to protection of the law. Finally, the Equal Protection Clause mandated that protection be afforded equally to all of the citizens of a state. In accord with the classical tradition, the Framers understood protection to include not only the right to a civil remedy and to protection under the criminal law, but also the state's responsibility to prevent violence.

In short, the reasoning at the core of DeShaney is indefensible. Far from showing that the Fourteenth Amendment was intended to prevent only the "affirmative abuse of power,"415 the congressional debates show that imposing a constitutional duty on the states to protect the fundamental rights of their citizens was a principal object of that Amendment.

More broadly, at the time of the adoption of the Bill of Rights and the Fourteenth Amendment, the Constitution was not regarded merely as "a charter of negative liberties."416 Instead, classical thought identified liberty not only with the absence of governmental coercion, but also with the positive protection of rights by the community. In the classical tradition, negative and positive liberty were viewed as essentially related. This is the conception of liberty that underlies the Fourteenth Amendment.

415. DeShaney v. Winnebago County Dep't of Social Servs., 489 U.S. 189, 196 (1989) (quoting Parratt v. Taylor, 451 U.S. 527, 549 (1981) (Powell, J., concurring in the result)).

416. Bowers v. DeVito, 686 F.2d 616, 618 (7th Cir. 1982). 